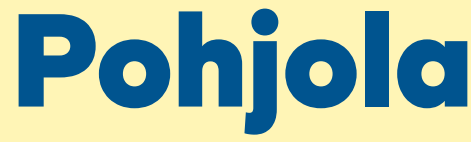

tilastoina

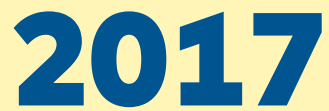

(11) Pohjoismaiden ministerineuvosto 


\section{Pohjola tilastoina 2017}

Toimittajat: Klaus Munch Haagensen, Danmarks Statistik (Tanskan tilastokeskus). Ulla Agerskov, Pohjoismaiden ministerineuvosto. Tietokanta: Troels A. Vestergaard, Danmarks Statistik (Tanskan tilastokeskus).

ANP 2017:749

ISBN 978-92-893-5103-4 (PRINT)

ISBN 978-92-893-5104-1 (PDF)

ISBN 978-92-893-5105-8 (EPUB)

ISSN 2414-6587 (ONLINE)

ISSN 2414-6579 (PRINT)

http://dx.doi.org/10.6027/ANP2017-749

(C) Pohjoismaiden ministerineuvosto 2017

Kuvat: Mette Agger Tang

Paino: Specialtrykkeriet ARCO

Printed in Denmark

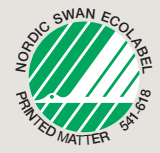

\section{Pohjoismainen yhteistyö}

Pohjoismainen yhteistyö on yksi maailman laajimmista alveellisista yhteistyömuodoista. Yhteistyön piiriin kuuluvat Islanti, Norja, Ruotsi, Suomi ja Tanska sekä Ahvenanmaa, Färsaaret ja Grönlanti.

Pohjoismaista yhteistyötä tehdään politiikan, talouden ja kulttuurin aloilla tärkeänä osana eurooppalaista ja kansainvälistä yhteistyötä. Pohjoismaisen yhteisön tavoitteena on vahva Pohjola vahvassa Euroopassa.

Pohjoismainen yhteistyö pyrkii vahvistamaan pohjoismaisia ja alveellisia etuja ja arvoja globaalissa maailmassa. Maiden yhteiset arvot lujittavat osaltaan Pohjolan asemaa yhtenä maailman innovatiivisimmista ja kilpailukykyisimmistä alueista. 
Pohjola

tilastoina

2017 
Lisää tilastoja osoitteessa

www.norden.org/tietoa 


\section{Esipuhe}

Pohjoismaat ovat yksittäin pieniä, mutta yhdessä niiden merkitys kasvaa. Tiesitkö, että Pohjola muodostaa maailman kahdenneksitoista suurimman talouden, kun maiden bruttokansantuotteet lasketaan yhteen? Tai että Pohjola on pinta-alaltaan suurempi kuin Intia, mikä tekee Pohjolasta maailman seitsemänneksi suurimman alueen?

Pohjola tilastoina 2017 antaa pienen katsauksen lukuihin, jotka kuvaavat Pohjolan yhteiskuntia. Tiesitkö esimerkiksi, että islantilaiset käyvät teatterissa kaksi kertaa niin usein kuin norjalaiset, tanskalaiset ja ruotsalaiset?

Mikäli haluat tutustua pohjoismaisiin tilastoihin tarkemmin, vieraile osoitteessa www.norden.org/tietoa. Sivustolta pääsee esimerkiksi pohjoismaiseen tilastopankkiin, jossa on lisää mielenkiintoisia lukuja vertailtavaksi.

Mukavia lukuhetkiä! 


\section{Symbolit}

Ei yhtään -

Vähemmän kuin puolet 0

Tieto ei ole sovellettavissa .

Tieto puuttuu

Linkki tietokantaan

\section{Maakoodit}

Tanska DK

Färsaaret FO

Grönlanti GL

Suomi FI

Ahvenanmaa AX

Islanti IS

Norja NO

Ruotsi SE

Pohjoismaat NR

Euroalue EA

Euroopan unioni EU 


\section{Sisältö / aihealueet}

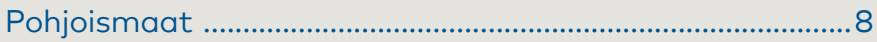

Pohjoismaat kansainvälisissä yhteyksissä ......................... 10

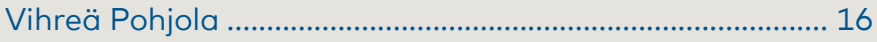

Tasa-arvo, elinkeinoelämä ja työ ............................................ 24

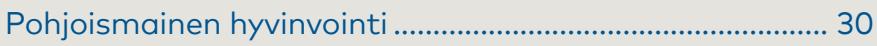

Lapset ja nuoret................................................................... 38

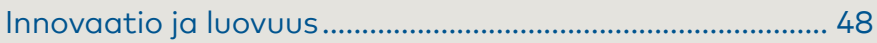

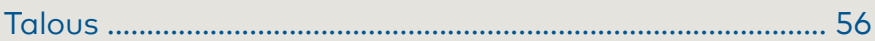




\section{Pohjoismaat}

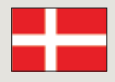

\section{Tanska}

Pinta-ala km²

42926

Väkiluku

5748769

Valtiomuoto

Perustuslaillinen monarkia

Valtionpäämies

Kuningatar Margareeta II

Pääkaupunki

1295686 (Kööpenhamina)

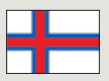

\section{Färsaaret}

Pinta-ala km²

Väkiluku

1396

Valtiomuoto

Valtionpäämies

Pääkaupunki

49864

Itsehallinto, osa Tanskan kuningaskuntaa Kuningatar Margareeta II 20885 (Tórshavn)

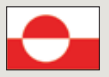

\section{Grönlanti}

Pinta-ala km²

Väkiluku

2166086

Valtiomuoto

Valtionpäämies

Pääkaupunki 55860

Itsehallinto, osa Tanskan kuningaskuntaa Kuningatar Margareeta II

17600 (Nuuk)

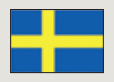

\section{Ruotsi}

Pinta-ala km²

Väkiluku

Valtiomuoto

Valtionpäämies

Pääkaupunki

\section{5}

9995153

Perustuslaillinen monarkia

Kuningas Kaarle XVI Kustaa

2269060 (Tukholma) 


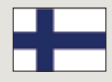

\section{Suomi}

Pinta-ala km²

Väkiluku

338430

Valtiomuoto

Valtionpäämies

Pääkaupunki

5503297

Tasavalta

Presidentti Sauli Niinistö

1138502 (Helsinki)

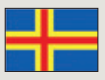

\section{Ahvenanmaa}

Pinta-ala km²

Väkiluku

1581

Valtiomuoto

29214

Valtionpäämies

Pääkaupunki

Itsehallinto, osa Suomen tasavaltaa

Presidentti Sauli Niinistö

11565 (Maarianhamina)

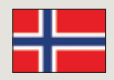

\section{Norja}

Pinta-ala km²

Väkiluku

Valtiomuoto

Valtionpäämies

Pääkaupunki

\section{1}

5258317

Perustuslaillinen monarkia

Kuningas Harald V

1281127 (Oslo)

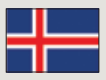

\section{Islanti}

Pinta-ala km²

Väkiluku

Valtiomuoto

Valtionpäämies

Pääkaupunki

103492

338349

Tasavalta

Presidentti Guðni Jóhannesson

216878 (Reykjavik) 


\section{AVAINLUVUT 2016*}

\section{Pohjoismaat}

\section{kansainvälisissä}

yhteyksissä

*2016 tai uusin saatavilla oleva luku. Tässä taulukossa Pohjoismaat käsittävät Suomen, Ruotsin, Norjan, Tanskan ja Islannin. PPS: Purchasing power standards ostovoimapariteetti, jonka avulla maiden välisiä hintaeroja on mahdollista vertailla eri hintatasosta huolimatta. 


\section{Pinta-ala}

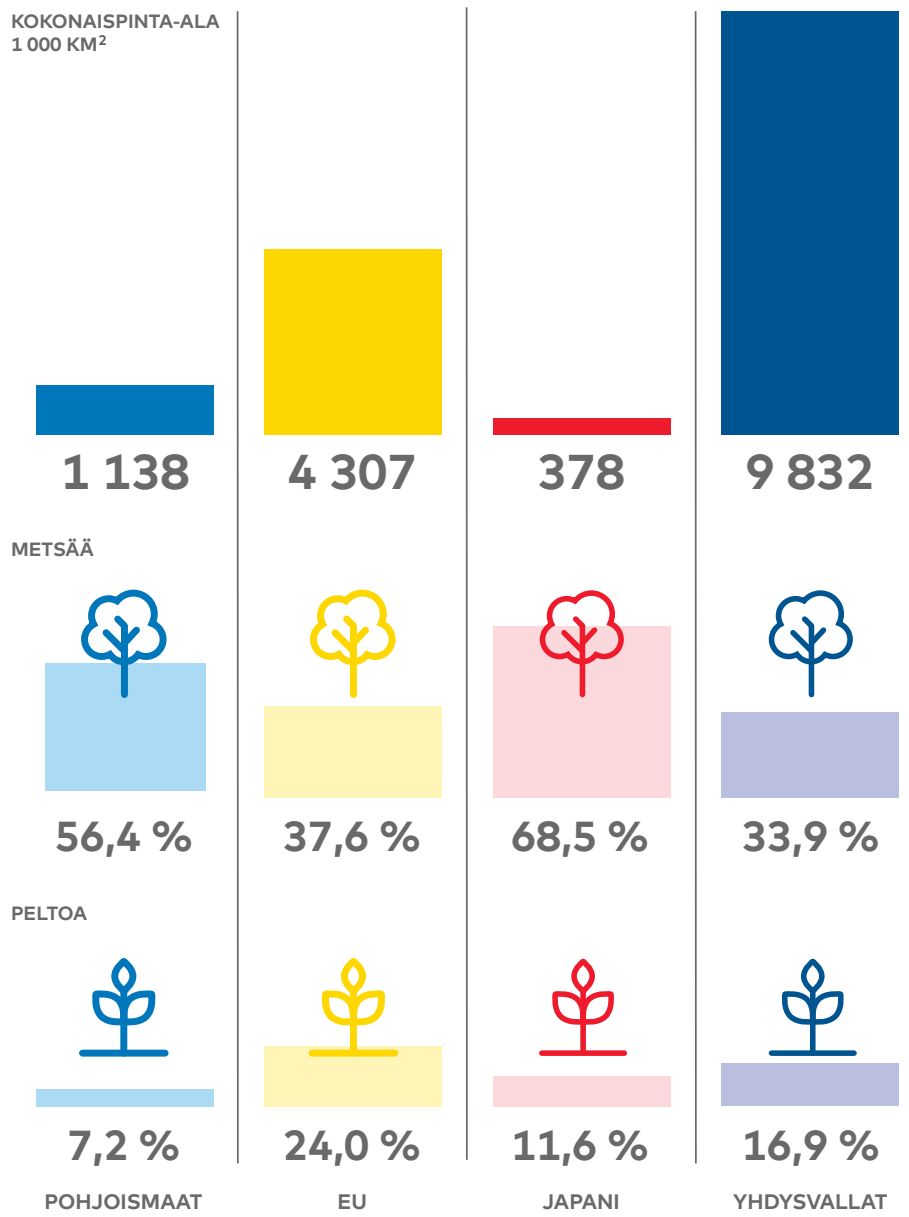




\section{Väkiluku}

miljoonaa

POHJOISMAAT

27 กัก

EU

JAPANI

YHDYSVALLAT

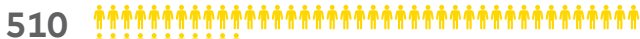

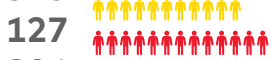

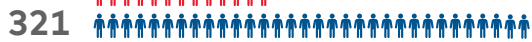

\section{Asukastiheys}

asukkaita $/ \mathrm{km}^{2}$

POHJOISMAAT

17

EU

118

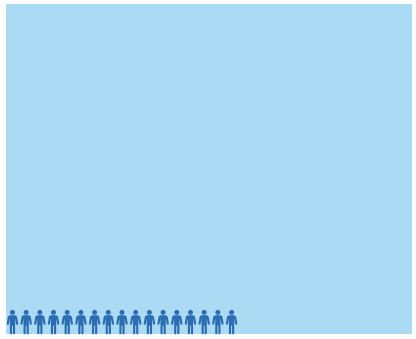

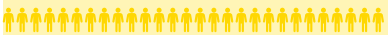

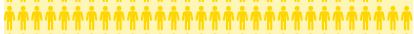

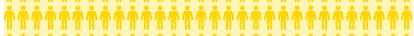

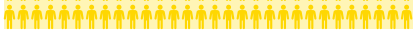

JAPANI

YHDYSVALLAT

348

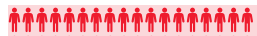

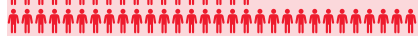

กำ

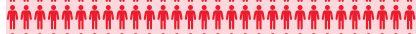

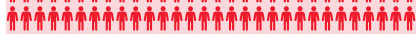

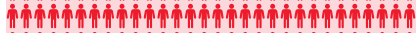

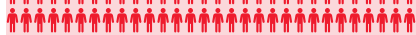

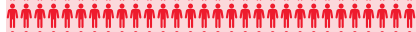

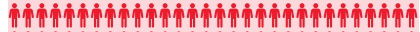

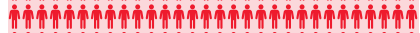

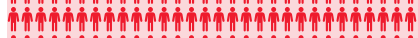

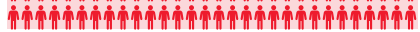

35 


\section{Kokonaishedelmällisyysluku}
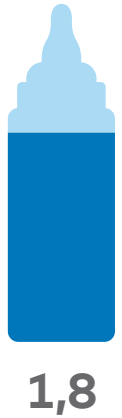

POHJOISMAAT
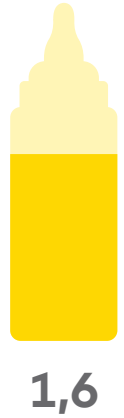

EU

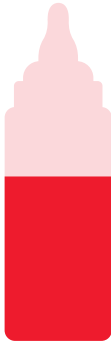

1,5

JAPANI

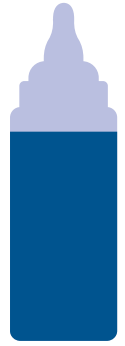

1,8

YHDYSVALLAT

\section{Elinajanodote}

vuotta

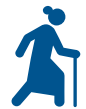

80

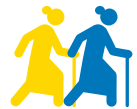

85

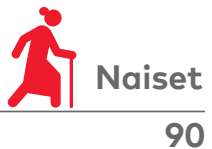

90

- YHDYSVALLAT, 81,2 EU, 83,3 $\bullet$ POHJOISMAAT, 83,8 $\bullet$ JAPANI, 87,1

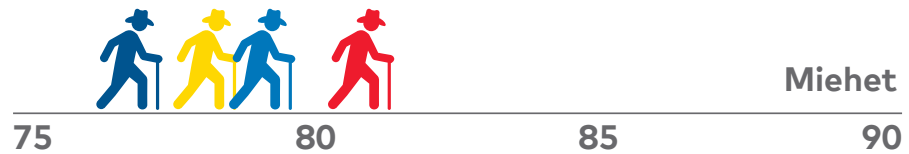

- YhdYSVALLAT, 74,4 EU, 77,9 POHJOISMAAT, 79,8 - JAPANI, 80,8 


\section{BKT}

BRUTTO-

KANSANTUOTE

PPS, USD
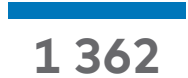

BKT ASUKASTA KOHDEN

PPS, USD

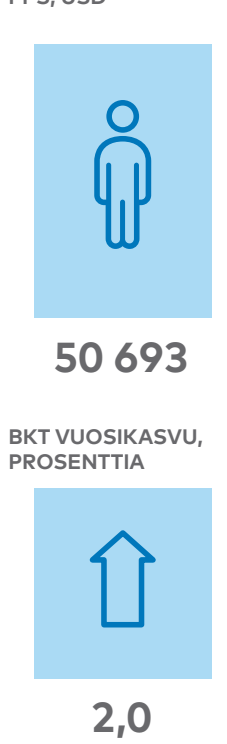

POHJOISMAAT

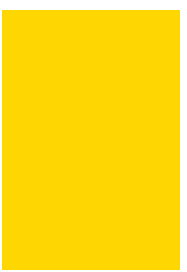

19904

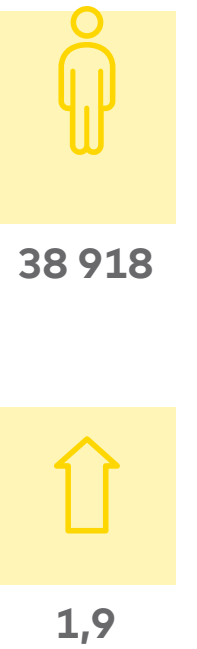

EU

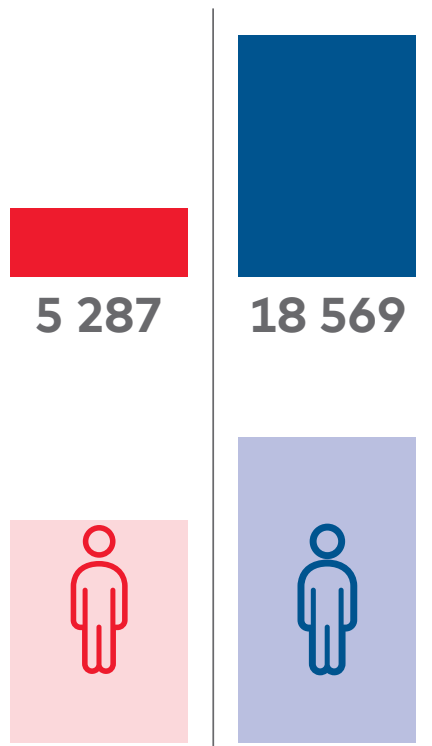

56066
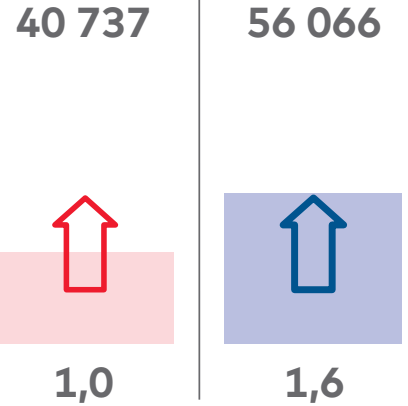

YHDYSVALLAT 


\section{Kokonaisveroaste}

prosenttia BKT:sta

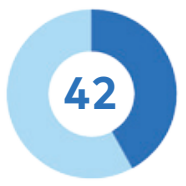

POHJOISMAAT

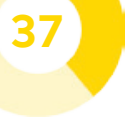

EU

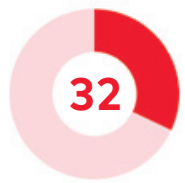

JAPANI

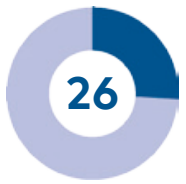

YHDYSVALLAT

\section{Tuonti ja vienti}

mrd. Yhdysvaltain dollaria

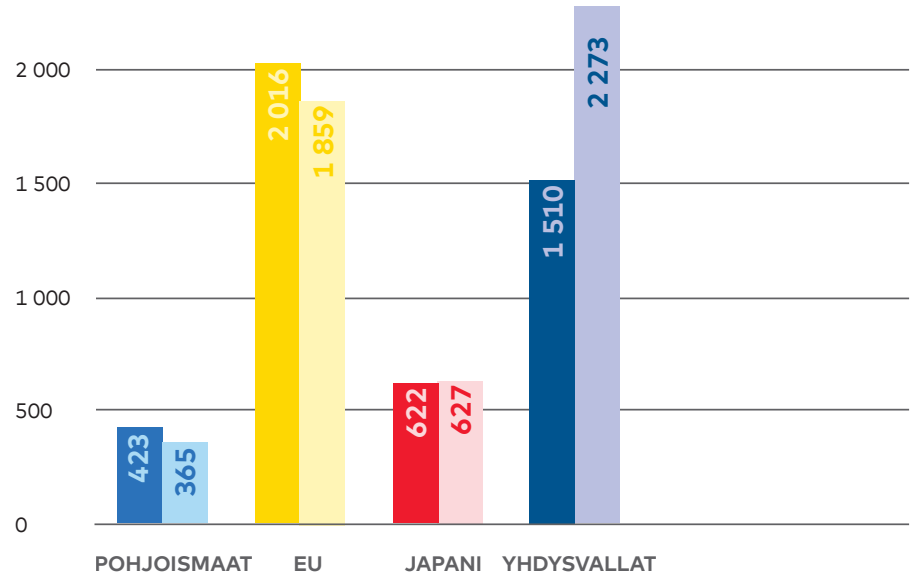




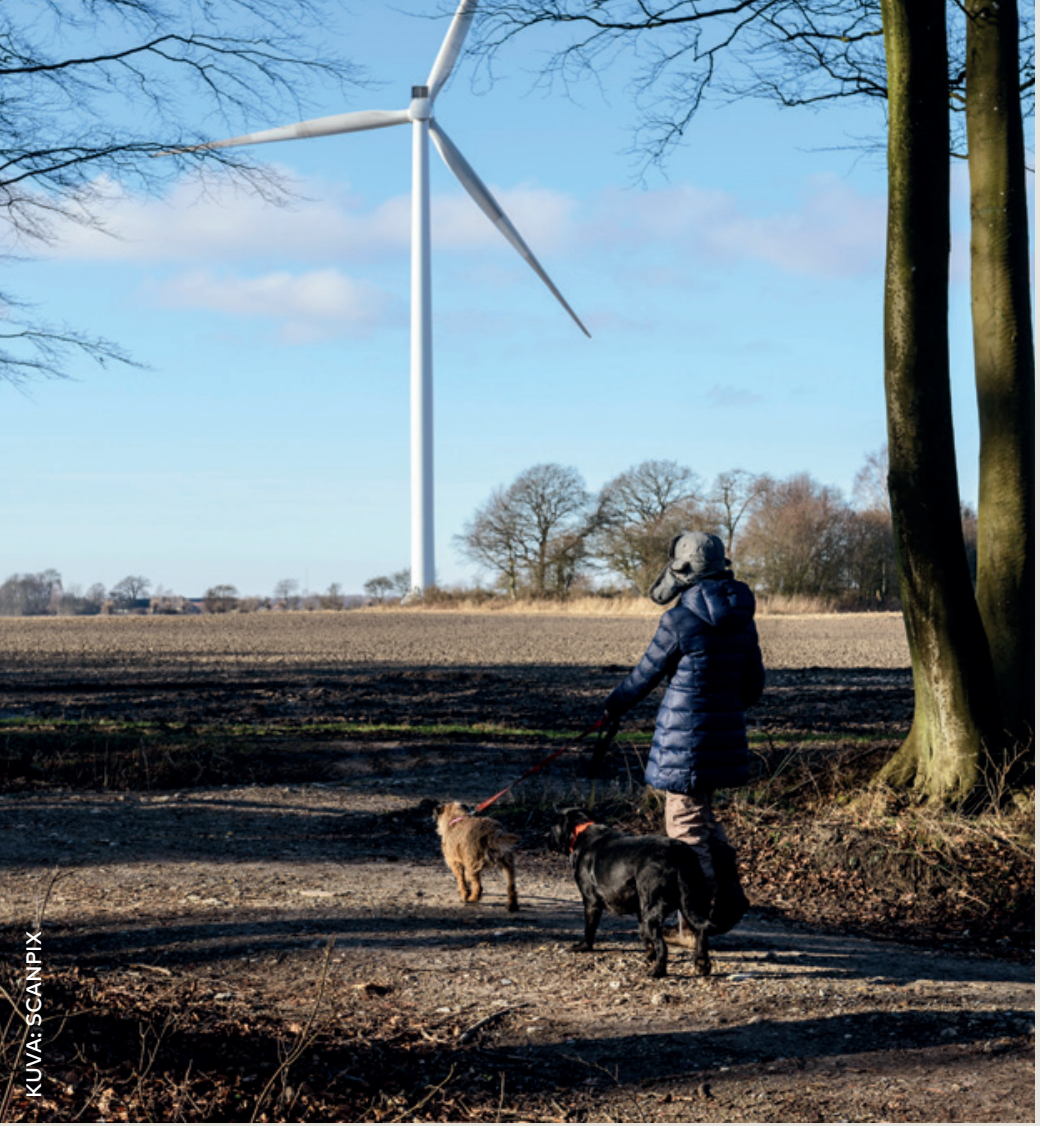

Vuoden 2000 jälkeen Pohjoismaiden taloudet ovat kasvaneet 28 prosentilla samaan aikaan, kun hiilidioksidipäästöt ovat supistuneet 18 prosentilla. 
Vihreä Pohjola 
Pohjoismaiden pääkaupunkien keskilämpötila

10 Celsiusastetta

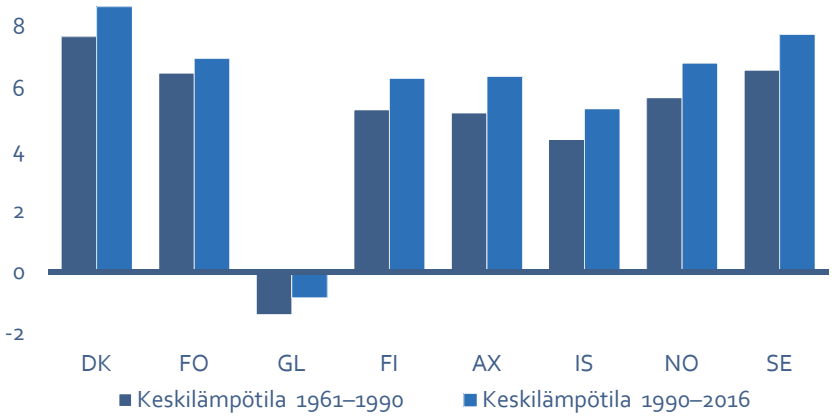

묘․ Tempo1. Islanti: tiedot vuosilta 1997-2016.

Kasvihuonekaasupäästöt asukasta kohden

$16 \mathrm{CO}_{2}$-ekvivalentit, tonnia

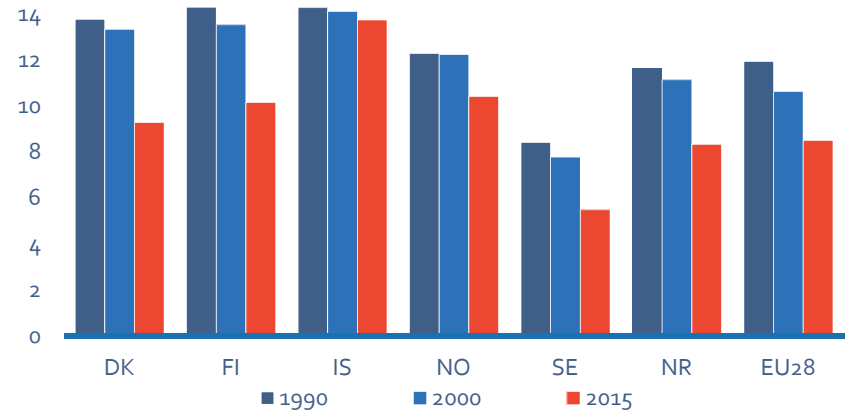

트is11 ja Popuo2 
Ympäristökuormituksen irtikytkentä talouskasvusta

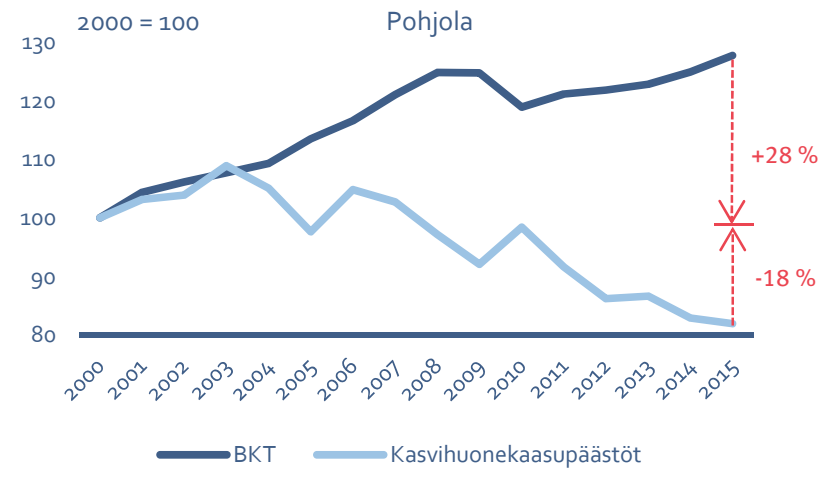

Emis11 ja Naaco1

Ympäristökuormituksen irtikytkentä talouskasvusta

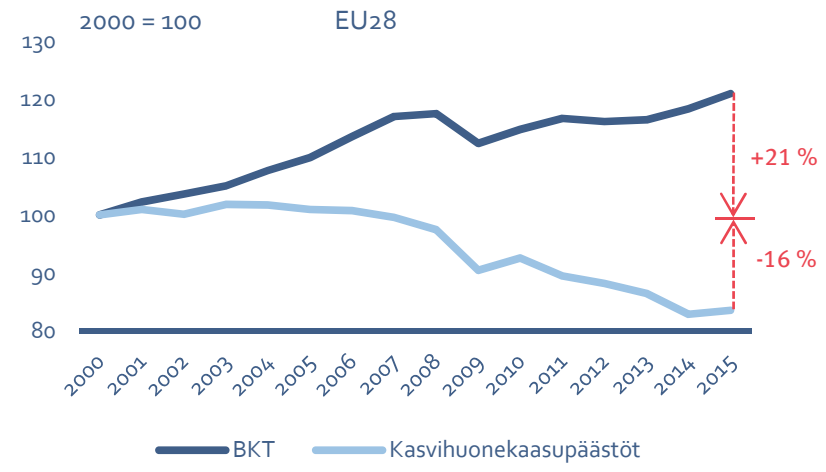

Emis11 ja Naaco1 


\section{Uusiutuva energia 2015}

prosenttia energian loppukäytöstä

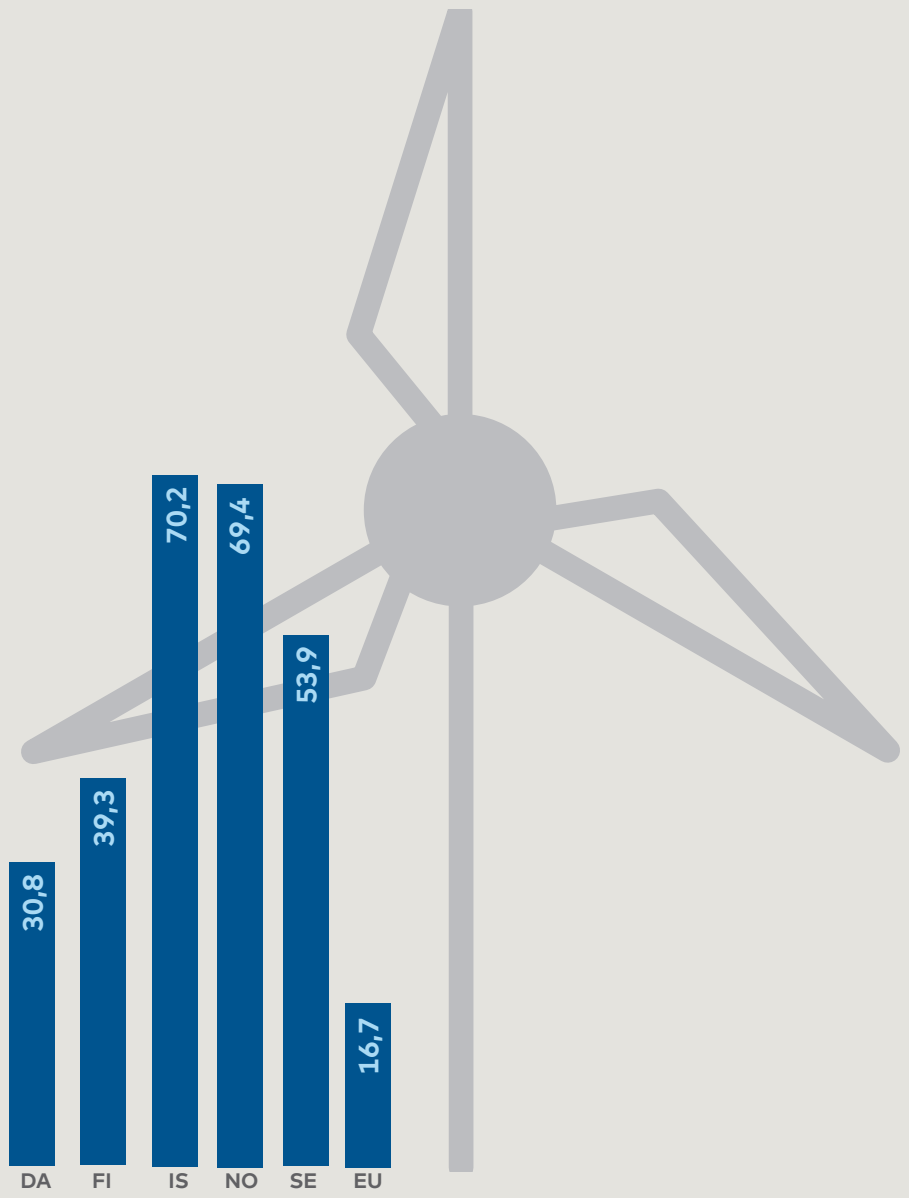




\section{Uusiutuva energia 2015}

prosenttia kokonaiskulutuksesta

$0 \%$

$100 \%$

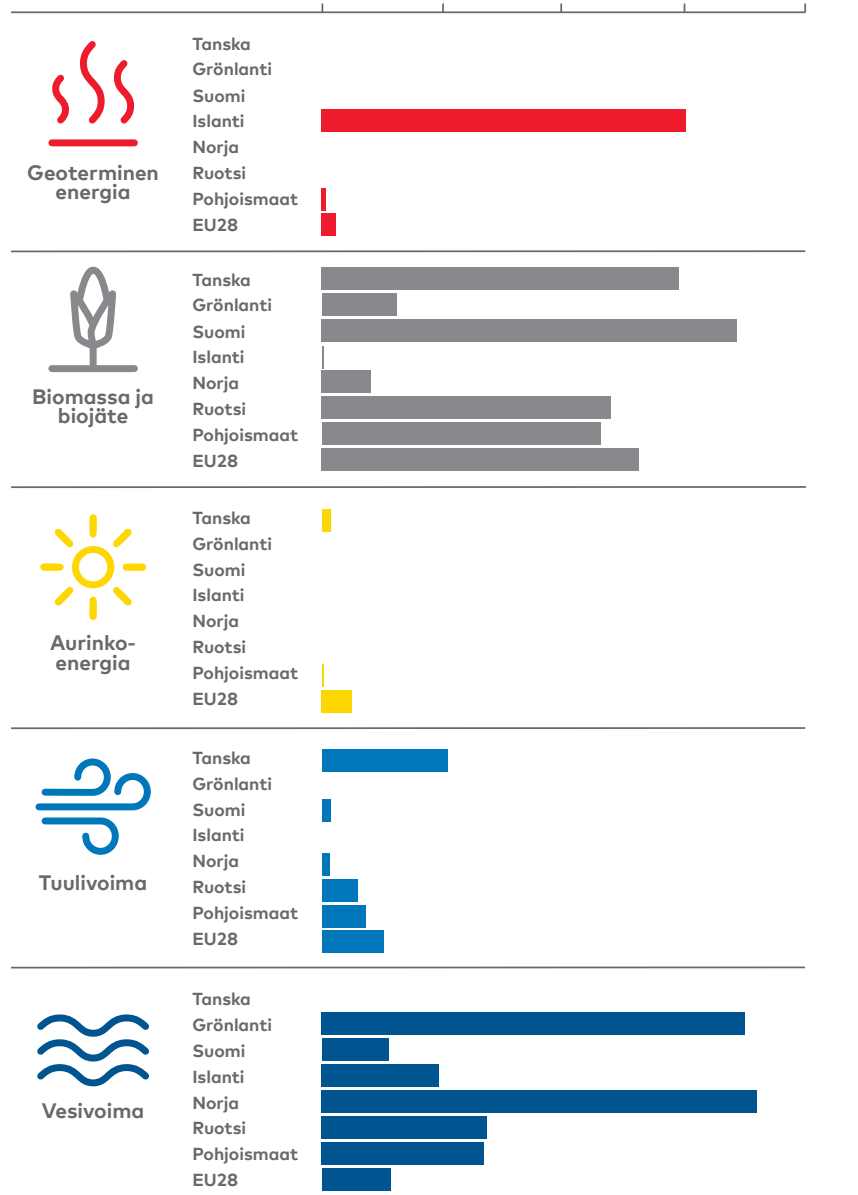


Kotoperäiset energialähteet 2015

Pohjola

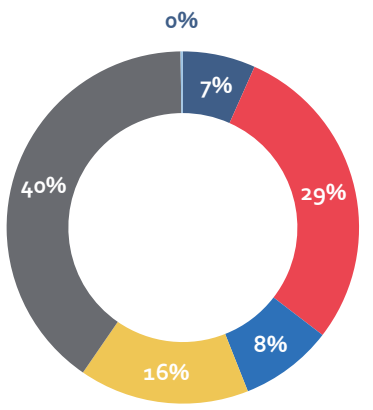

- Hiili

• Öljy

- Kaasu

- Ydinvoima

- Uusiutuva energia

Muut

모 Enero5

Kotoperäiset energialähteet 2015

$\mathrm{EU}_{28}$

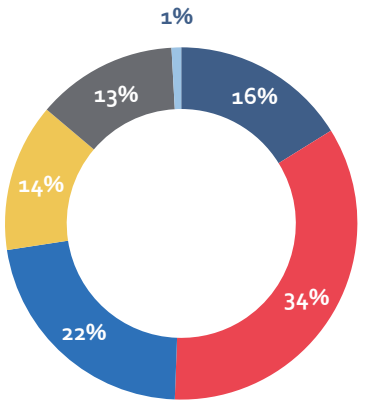

- Hiili

- Öljy

- Kaasu

- Ydinvoima

- Uusiutuva energia

Muut

몰 En 


\section{Ympäristöverot}

8 Prosenttia kaikista veroista

6

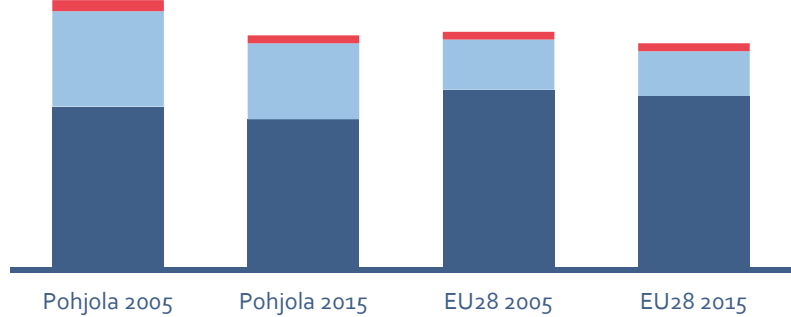

— Pilaantumiseen ja luonnonvarojen käyttöön liittyvät verot

- Liikenneverot

- Energiaverot

Envtxo1 


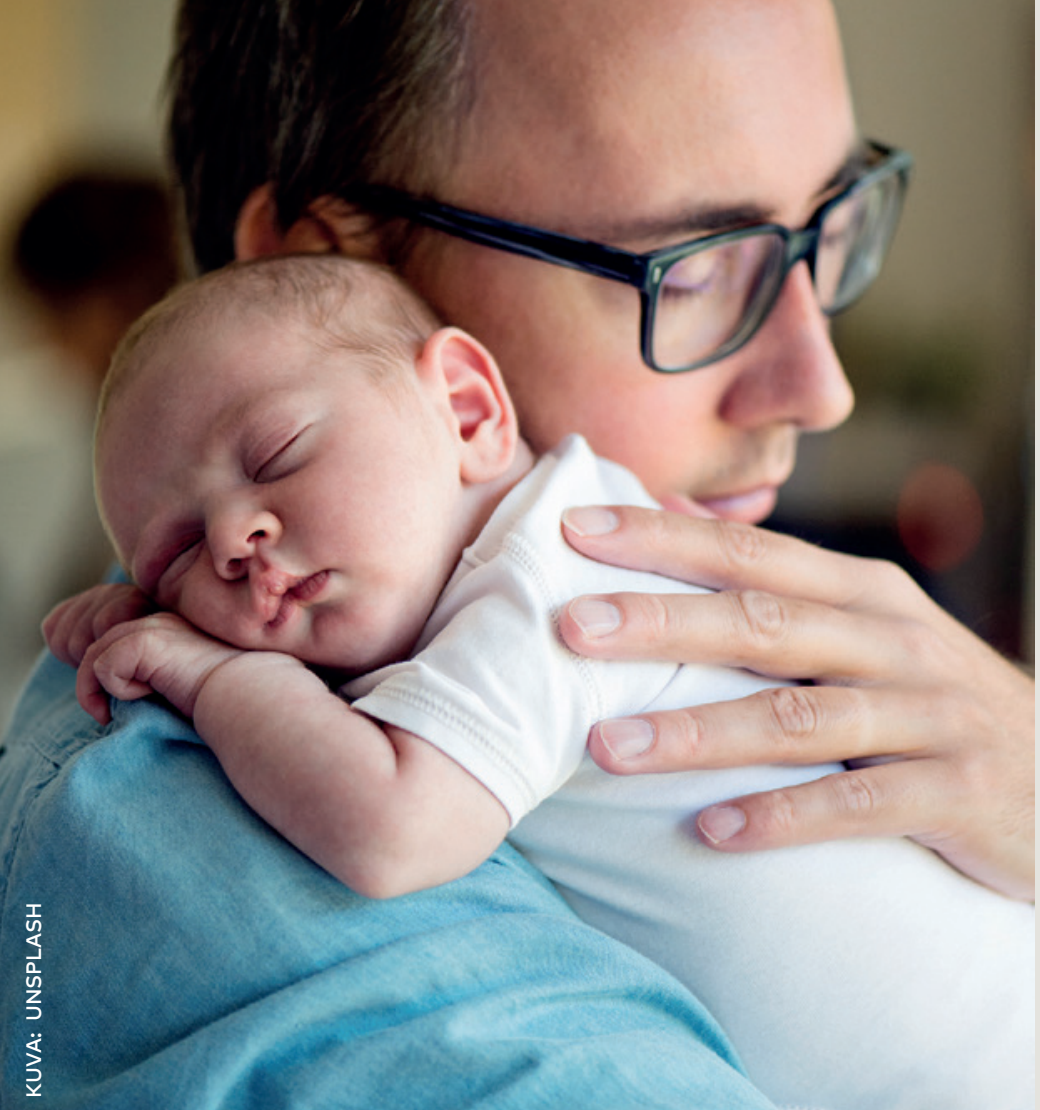

Pohjoismaissa seitsemän kymmenestä naisesta käy töissä. EU:n keskiarvo on viisi kymmenestä naisesta. 


\section{Tasa-arvo, elinkeinoelämä ja työ}




\section{Työllisyysaste 2016}

100 Prosenttia kaikista 15-64-vuotiaista

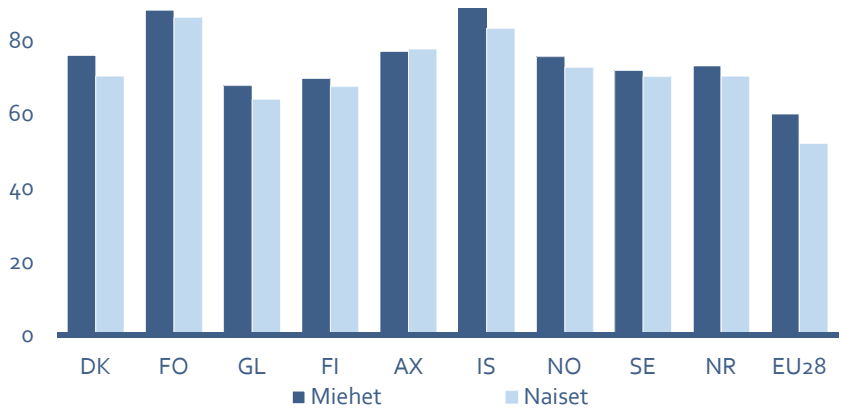

ㅁ Work02. Grönlanti: tiedot vuodelta 2014. Ahvenanmaa: tiedot vuodelta 2015.

\section{Työttömyysaste 2016}

10 Prosenttia kaikista 15-64-vuotiaista

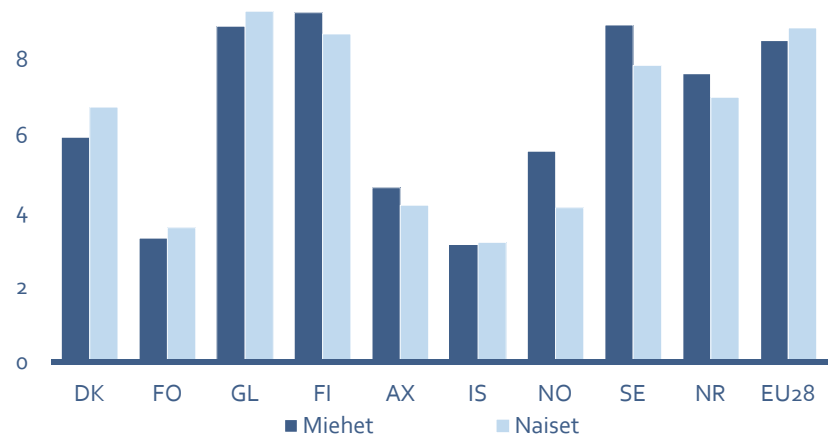

马 Worko2. Grönlanti ja Ahvenanmaa: tiedot vuodelta 2015. 
Työvoima sukupuolen mukaan 2016

Pohjola

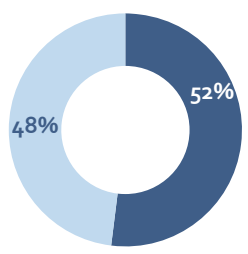

$\mathrm{EU}_{28}$

- Miehet

Naiset

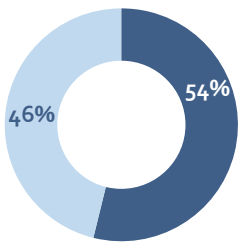

ㅁ Worko2

\section{Sukupuolten välinen palkkaero} prosenttia
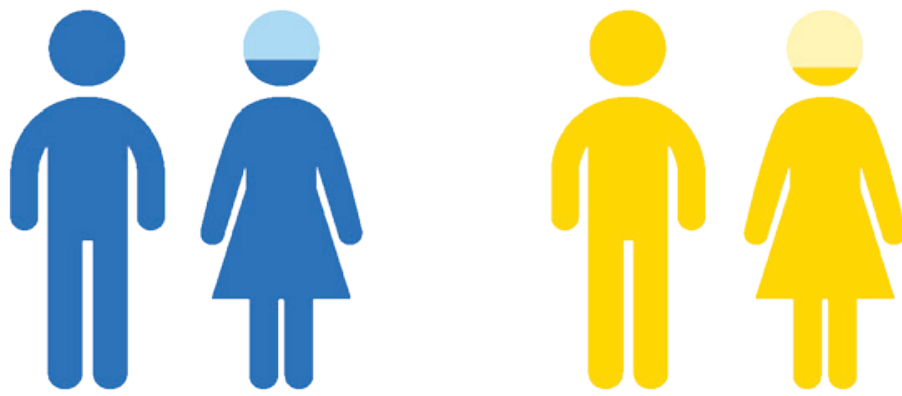

$$
15,3
$$

16,3

EU28

POHJOISMAAT 
Suurimpien julkisesti noteerattujen yhtiöiden hallituksen jäsenet 2015

Prosenttia

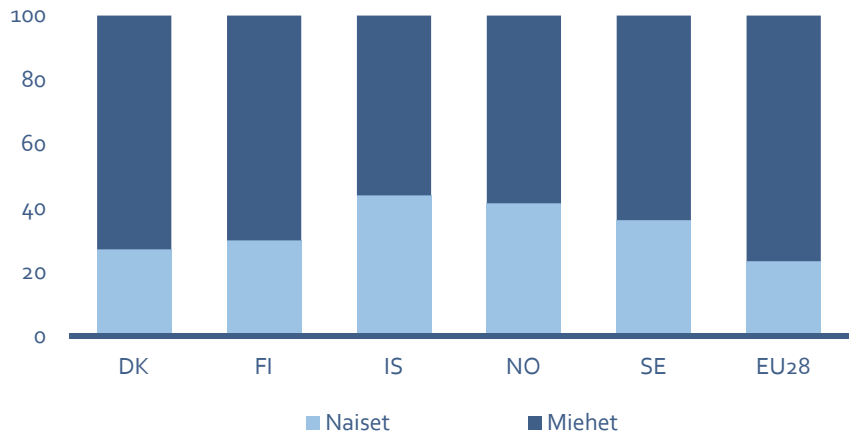

皿 Laboo8

Työnantajien osuus työllisistä 2015

7 Prosenttia

6

\begin{tabular}{l}
\hline \\
\hline DK \\
\hline- \\
\hline
\end{tabular}

4

3

2

1

o

DK

Naiset

IS

S NO

NO SE

- Miehet

$\square$ Laboog 
Isien osuus käytetyistä perhevapaista prosenttia

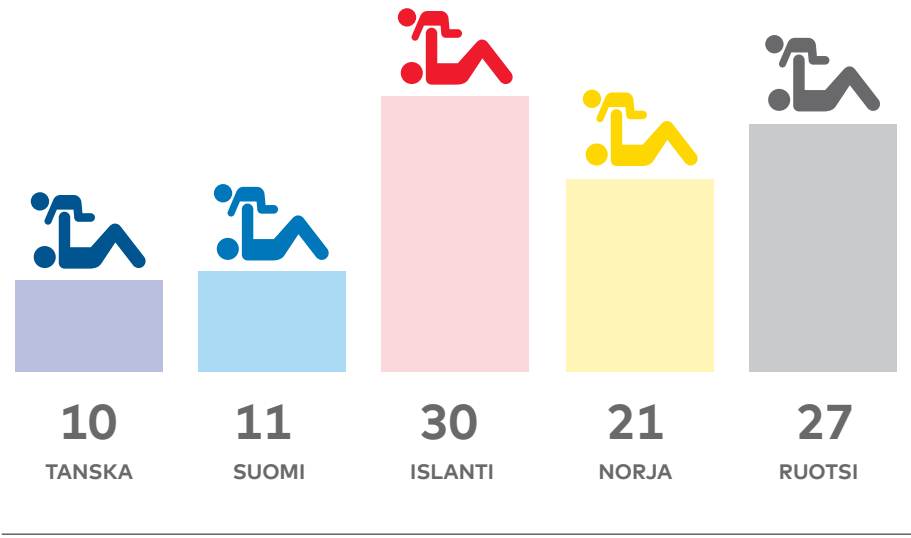

Isyys- ja vanhempainvapaa

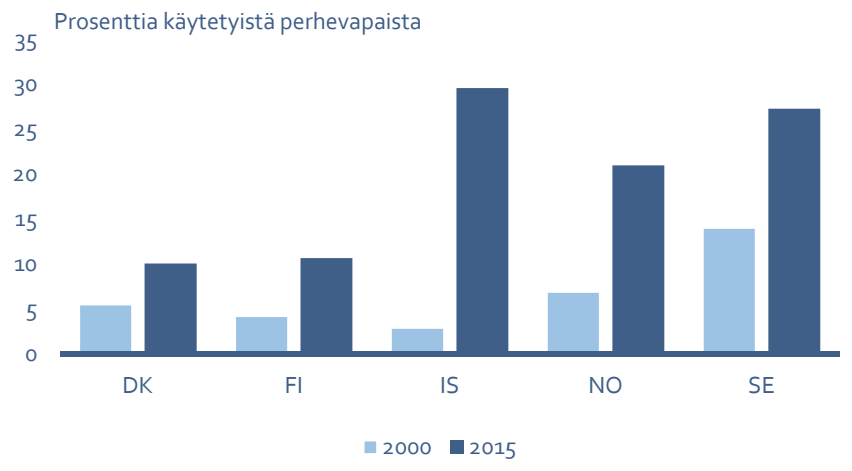

@ Socio4 
Pohjoismainen hyvinvointi 


\section{Gini-kerroin}

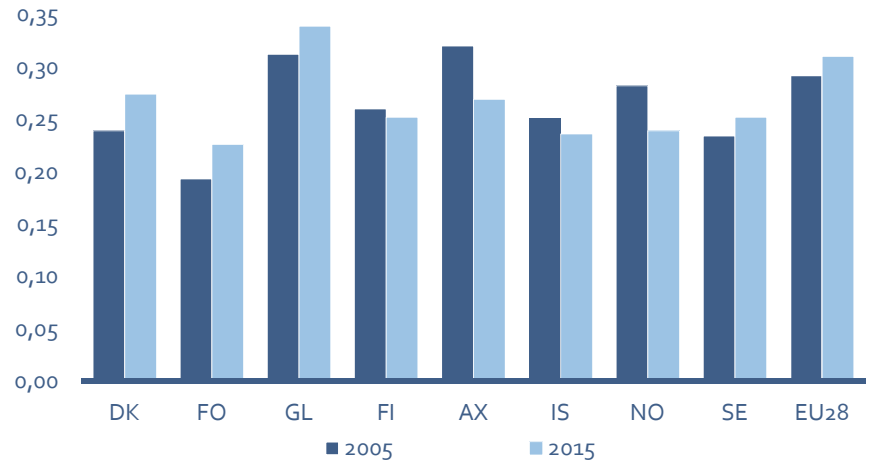

口 Ginio1. Färsaaret: tiedot vuosilta 2009 ja 2014. Ahvenanmaa: tiedot vuodelta 2014.

\section{Köyhyysriski 2016}

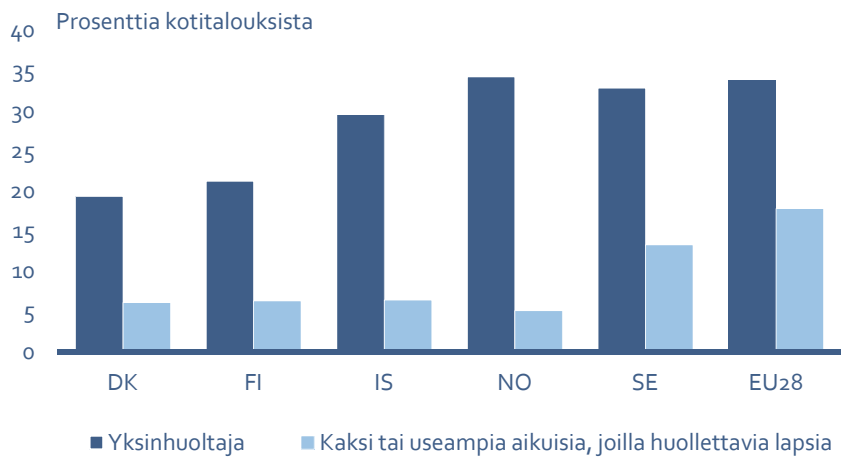

口 Riopo1. Islanti ja EU28: tiedot vuodelta 2015. 


\section{Toimeentulotuen saajat}

4

Prosenttia yli 18-vuotiaista

3

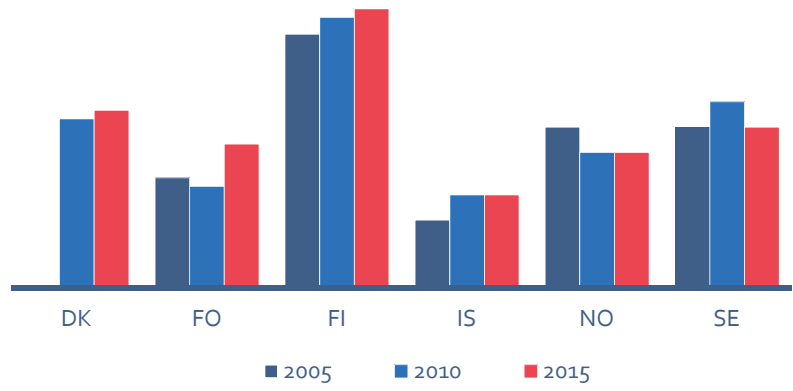

Soci12.Suomi: vuoden 2015 tiedot ovat vuodelta 2014.

Sosiaalimenojen rahoituksen lähteet 2014

Prosenttia kaikista rahoituksen lähteistä

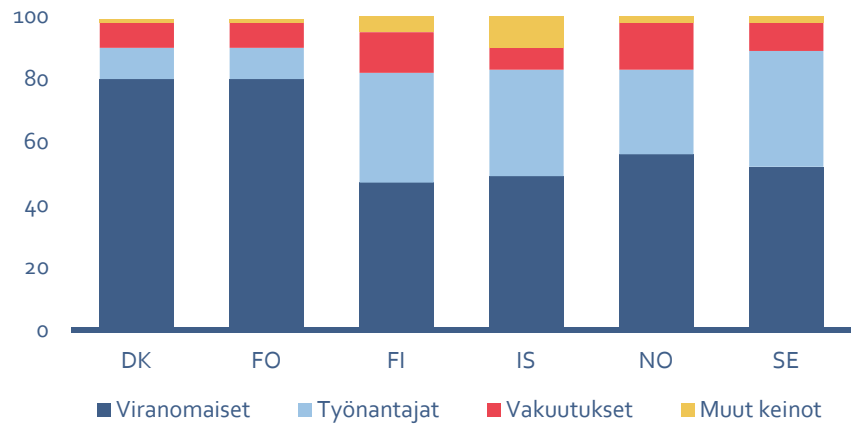

马oexo6 


\section{Vanhusväestö (65 vuotta täyttäneet)}

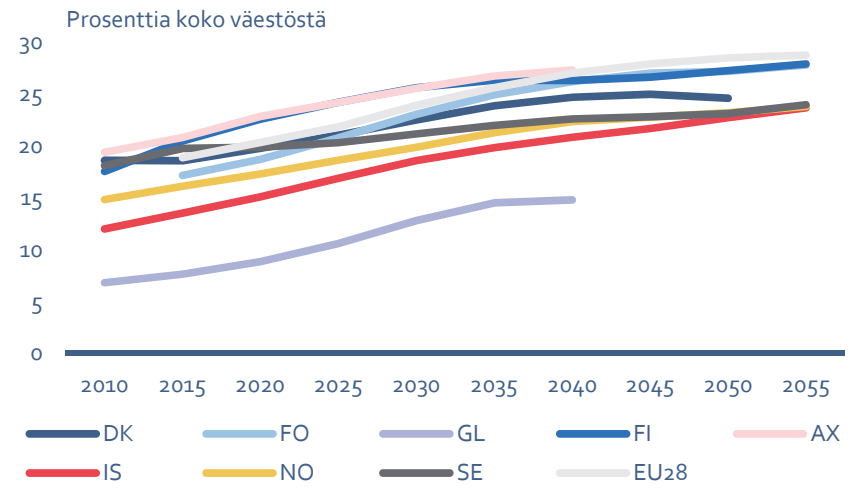

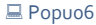

Syöpäkuolleisuus 2014

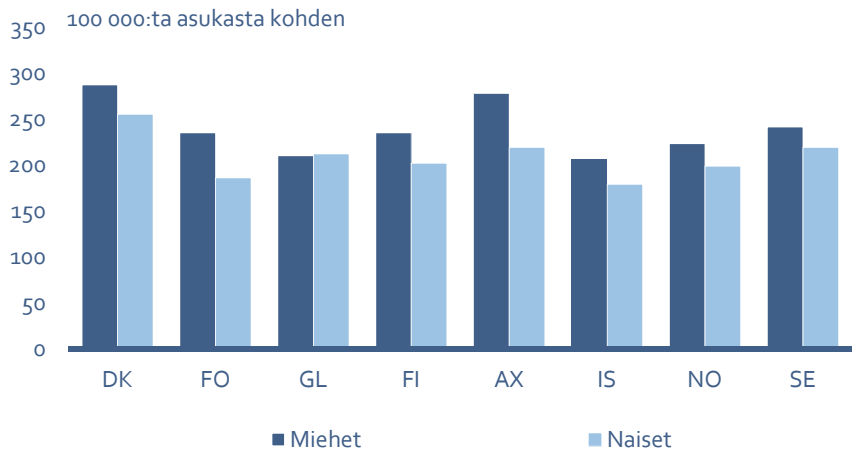

ㅁ Healo3 
Kokonaishedelmällisyysluku 2016

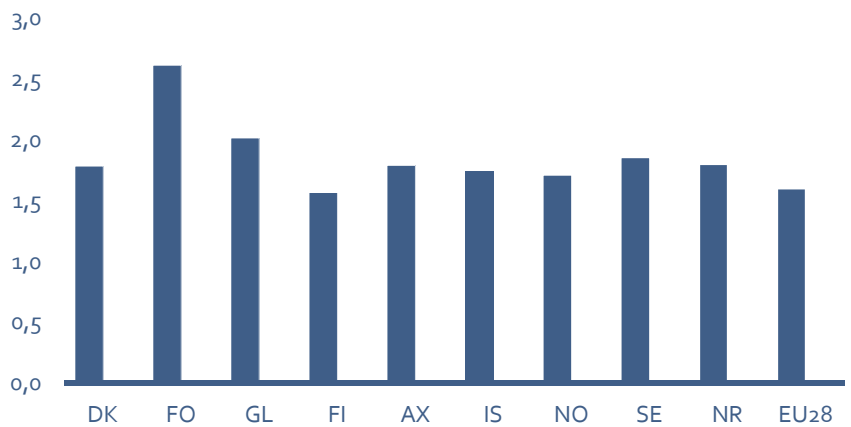

马 Chilo2. Grönlanti: tiedot vuodelta 2015.

Keskimääräinen elinikä 2016

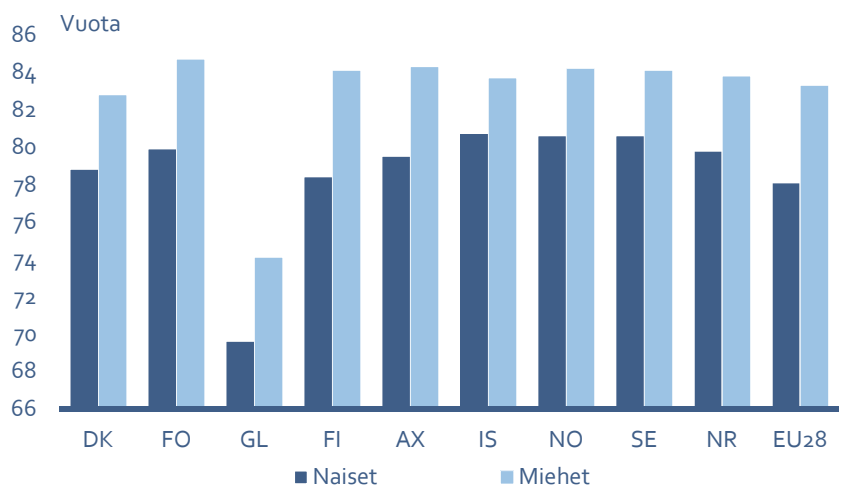

马 Life01. Grönlanti, Ahvenanmaa ja EU28: tiedot vuodelta 2015. 
Turvapaikkahakemukset Pohjoismaissa 2016

Hakemusten osuus

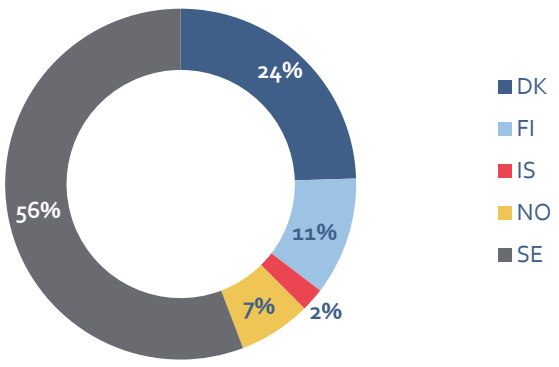

昌 Migro4

Turvapaikkahakemukset ja myönteiset päätökset Pohjoismaissa

250000

200000

150000

100000

50000

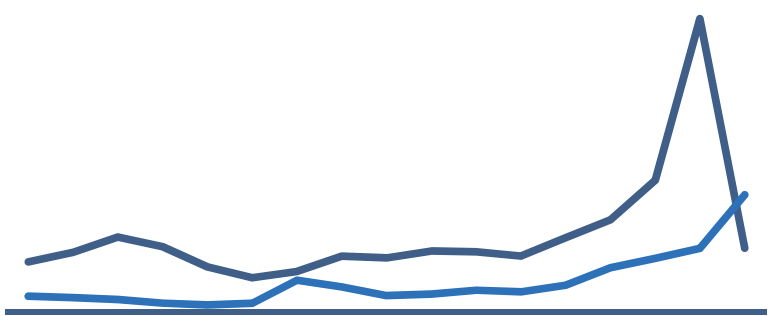

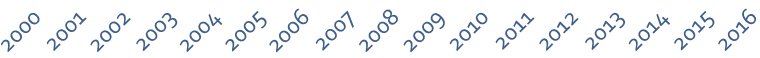

$$
\begin{aligned}
& \longrightarrow \text { Hakemukset Myönteiset päätökset }
\end{aligned}
$$

㽞 Migro4 


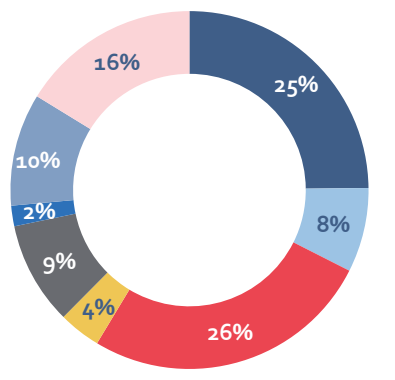

- Pohjoismaiden välinen

- Puola ja Baltia

muv ETA

Muu Eurooppa

- Amerikka

- Afrikka

Aasia

Muut

Migro2

Maahanmuutto Pohjoismaihin 2016

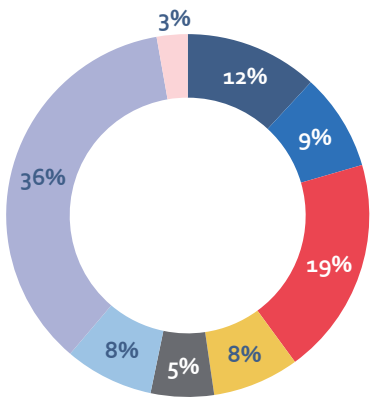

- Pohjoismaiden välinen

- Puola ja Baltia

- Muu ETA

- Muu Eurooppa

amerikka

Afrikka

- Aasia

Muut

@ Migro1 


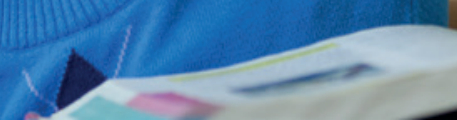

Pohjoismaiden koululaiset yltävät PISA-tuloksissa yli OECD-maiden keskiarvon lukemisessa, matematiikassa ja luonnontieteissä. 
Lapset ja nuoret 
Suosituimmat vuonna 2016 syntyneiden nimet

TANSKA

GRÖNLANTI

FÄRSAARET

SUOMI

AHVENANMAA

ISLANTI (2015)

NORJA

RUOTSI

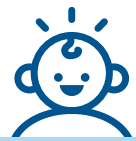

Sofia

Nivi

Anna

Sofia

Alice

Emilia

Nora

Alice

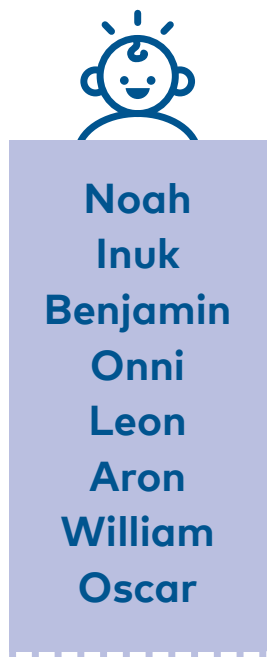


Päivähoidossa olevat 3-5-vuotiaat lapset

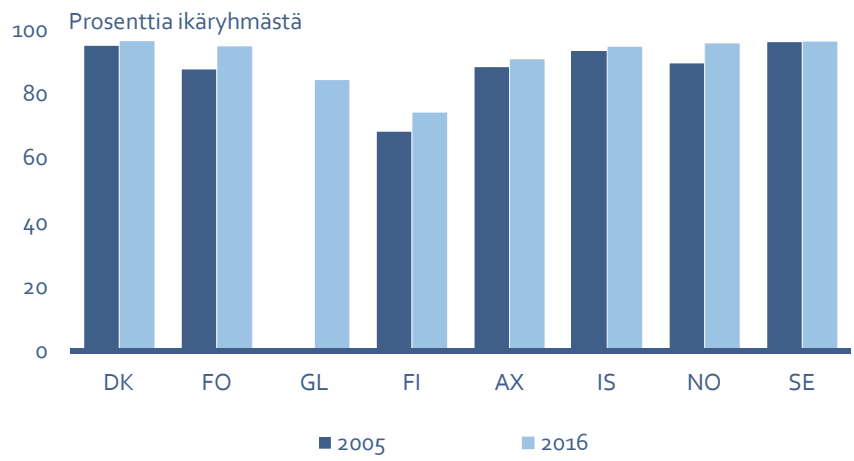

马 Chilo3. Tanska: tiedot vuodelta 2014. Suomi ja Islanti: tiedot vuodelta 2015.

Ekvivalenttien tulojen kehitys 2005-2015

6o Prosentuaalinen kasvu

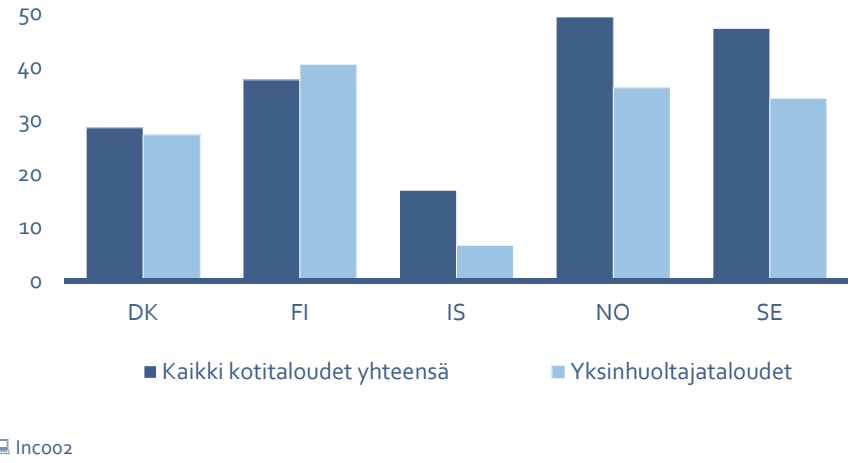




\title{
Koululaisten osaaminen
}

\author{
PISA 2015
}

\begin{tabular}{|c|c|c|c|c|c|}
\hline \multicolumn{2}{|l|}{ Lukutaito } & \multicolumn{2}{|c|}{ Matematiikan osaaminen } & \multicolumn{2}{|c|}{ Luonnontieteen osaaminen } \\
\hline Kanada & 527 & Japani & 532 & Japani & 538 \\
\hline Suomi & 526 & Etelä-Korea & 524 & Viro & 534 \\
\hline Irlanti & 521 & Sveitsi & 521 & Suomi & 531 \\
\hline Viro & 519 & Viro & 520 & Kanada & 528 \\
\hline Etelä-Korea & 517 & Kanada & 516 & Etelä-Korea & 516 \\
\hline Japani & 516 & Alankomaat & 512 & Slovenia & 513 \\
\hline Norja & 513 & Suomi & 511 & Uusi-Seelanti & 513 \\
\hline Saksa & 509 & Tanska & 511 & Australia & 510 \\
\hline Uusi-Seelanti & 509 & Slovenia & 510 & Alankomaat & 509 \\
\hline Puola & 506 & Belgia & 507 & Saksa & 509 \\
\hline Slovenia & 505 & Saksa & 506 & Yhd. kuningask. & 509 \\
\hline Australia & 503 & Irlanti & 504 & Sveitsi & 506 \\
\hline Alankomaat & 503 & Puola & 504 & Irlanti & 503 \\
\hline Tanska & 500 & Norja & 502 & Tanska & 502 \\
\hline Ruotsi & 500 & Itävalta & 497 & Belgia & 502 \\
\hline Belgia & 499 & Uusi-Seelanti & 495 & Puola & 501 \\
\hline Ranska & 499 & Australia & 494 & Portugali & 501 \\
\hline Portugali & 498 & Ruotsi & 494 & Norja & 498 \\
\hline Yhd. kuningask. & 498 & Ranska & 493 & Yhdysvallat & 496 \\
\hline Yhdysvallat & 497 & Portugali & 492 & Itävalta & 495 \\
\hline Espanja & 496 & Yhd. kuningask. & 492 & Ranska & 495 \\
\hline OECD:n keskiarvo & 493 & Tšekki & 492 & Ruotsi & 493 \\
\hline Sveitsi & 492 & OECD:n keskiarvo & 490 & Tšekki & 493 \\
\hline Latvia & 488 & Italia & 490 & OECD:n keskiarvo & 493 \\
\hline Tšekki & 487 & Islanti & 488 & Espanja & 493 \\
\hline Itävalta & 485 & Espanja & 486 & Latvia & 490 \\
\hline Italia & 485 & Luxemburg & 486 & Luxemburg & 483 \\
\hline Islanti & 482 & Latvia & 482 & Italia & 481 \\
\hline Luxemburg & 481 & Färsaaret & 482 & Unkari & 477 \\
\hline Israel & 479 & Unkari & 477 & Islanti & 473 \\
\hline Färsaaret & 470 & Slovakia & 475 & Israel & 467 \\
\hline Unkari & 470 & Yhdysvallat & 470 & Slovakia & 461 \\
\hline Kreikka & 467 & Israel & 470 & Kreikka & 455 \\
\hline Chile & 459 & Kreikka & 454 & Chile & 447 \\
\hline Slovakia & 453 & Chile & 423 & Färsaaret & 446 \\
\hline Turkki & 428 & Turkki & 420 & Turkki & 425 \\
\hline Meksiko & 423 & Meksiko & 408 & Meksiko & 416 \\
\hline
\end{tabular}

马 Pisao1 


\section{PISA 2015}

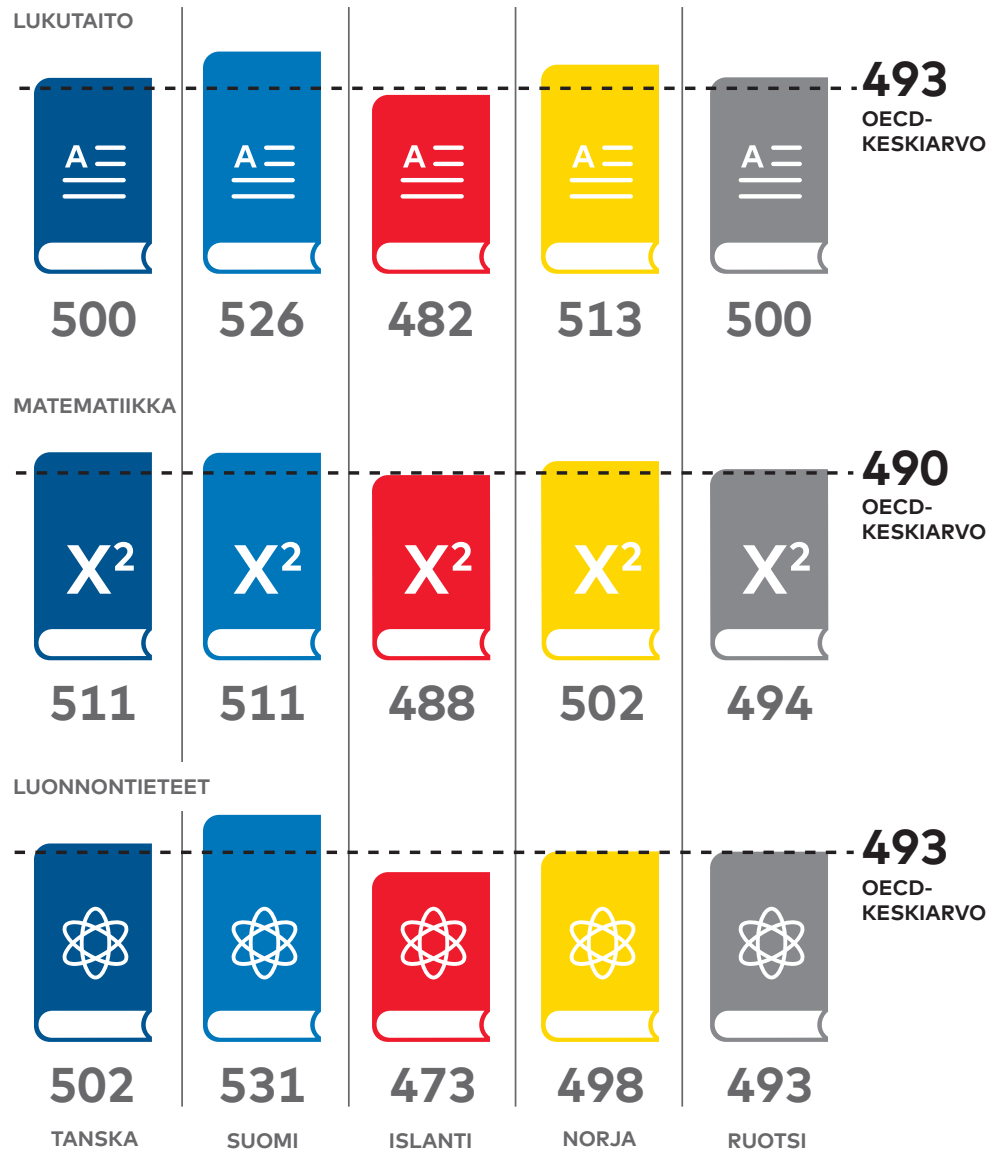


Yliopisto- ja korkeakouluopiskelijat 2015

Prosenttia kaikista 20-39-vuotiaista

20

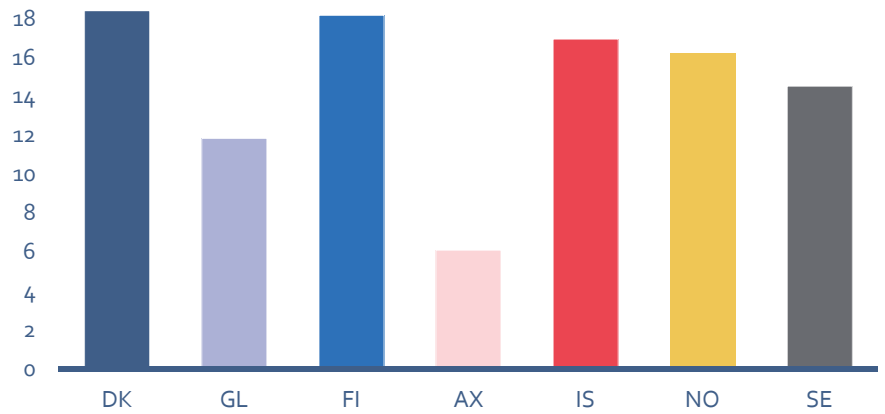

口 Educ02 ja Popu02. Grönlanti: tiedot vuodelta 2012. Ahvenanmaa: Sisältää ainoastaan Ahvenanmaan ammattikorkeakoulun opiskelijat. Ruotsi: tiedot vuodelta 2014 .

Yliopisto- ja korkeakouluopiskelijat

16 Prosenttia kaikista 20-39-vuotiaista, Pohjola yhteensä

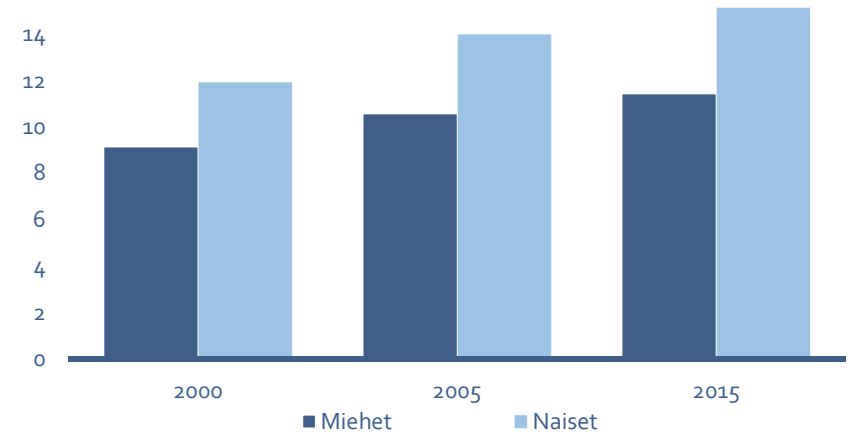

툘oc02 ja Popuo2 


\section{Ulkomailla opiskelevat opiskelijat}

muissa Pohjoismaissa opiskelevien osuus, prosenttia

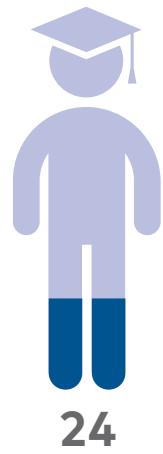

TANSKA

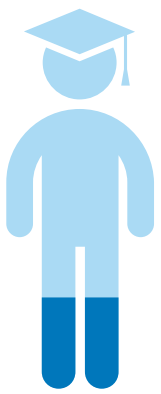

24

SUOMI

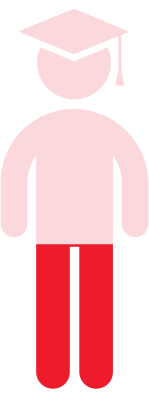

38

ISLANTI

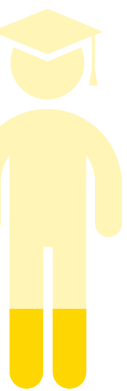

21

NORJA

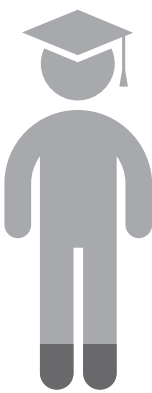

12

RUOTSI

Pohjoismaalaiset opiskelijat muissa Pohjoismaissa 2016

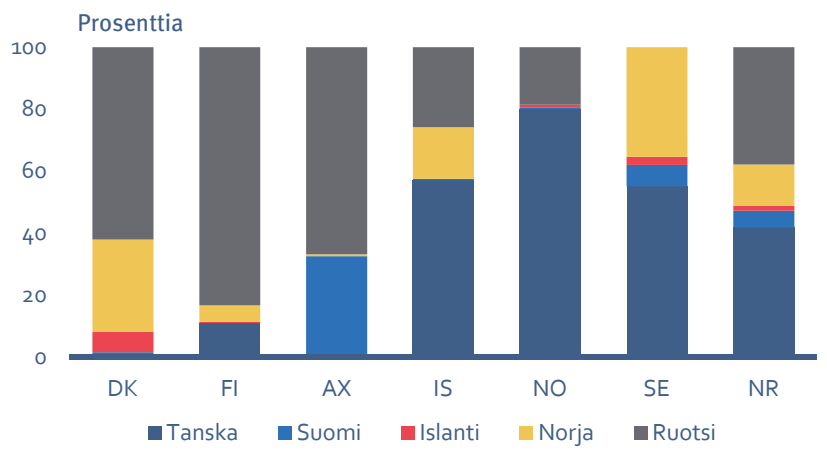




\section{Nuorisotyöttömyys}

25 Prosenttia kaikista 15-24-vuotiaista

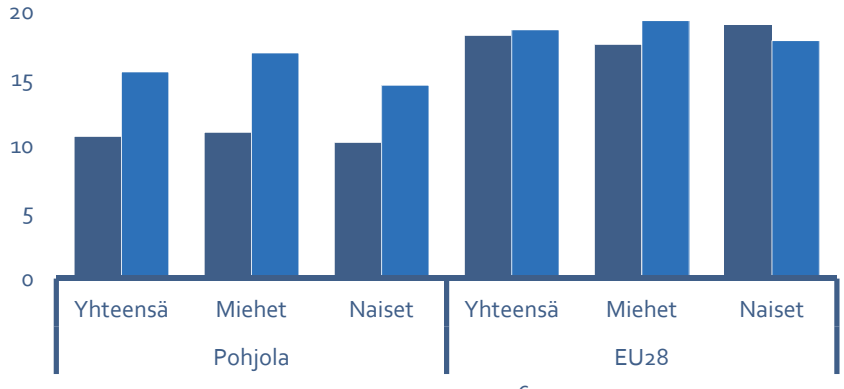

- $2000 \square 2016$

口 Worko2 

Innovaatio ja luovuus 


\section{Tutkimus- ja kehittämistoiminnan henkilöstö}

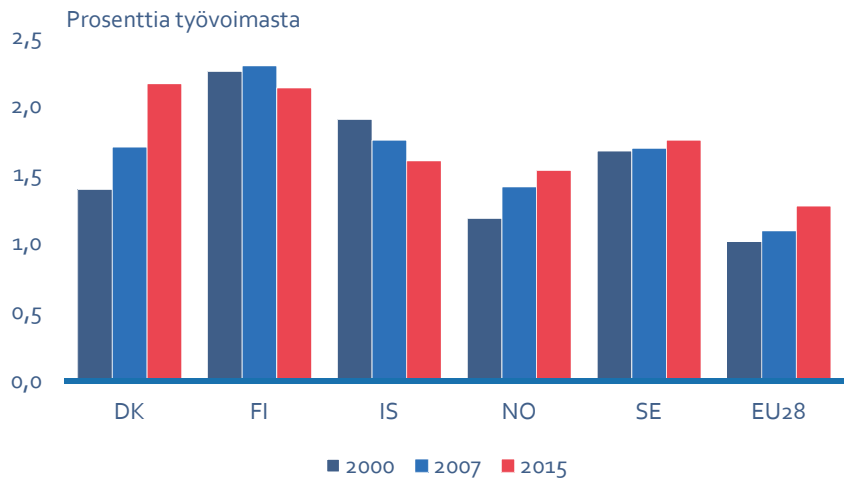

品 Rede04. Islanti: vuoden 2000 tiedot ovat vuodelta 2003. Norja ja Ruotsi: vuoden 2000 tiedot ovat vuodelta 2001. EU28: vuoden 2000 tiedot ovat vuodelta 2002.

Valtion tutkimus- ja kehittämistoiminnan menot

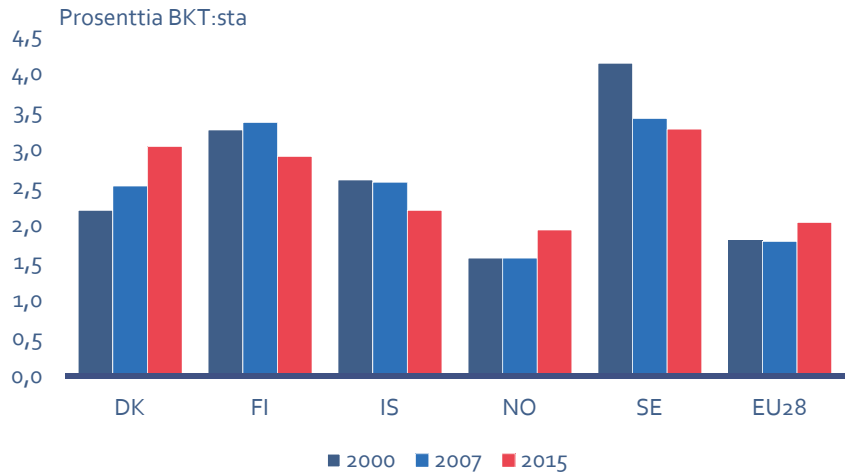

口 Redeo1. Norja ja Ruotsi: vuoden 2000 tiedot ovat vuodelta 2001. 


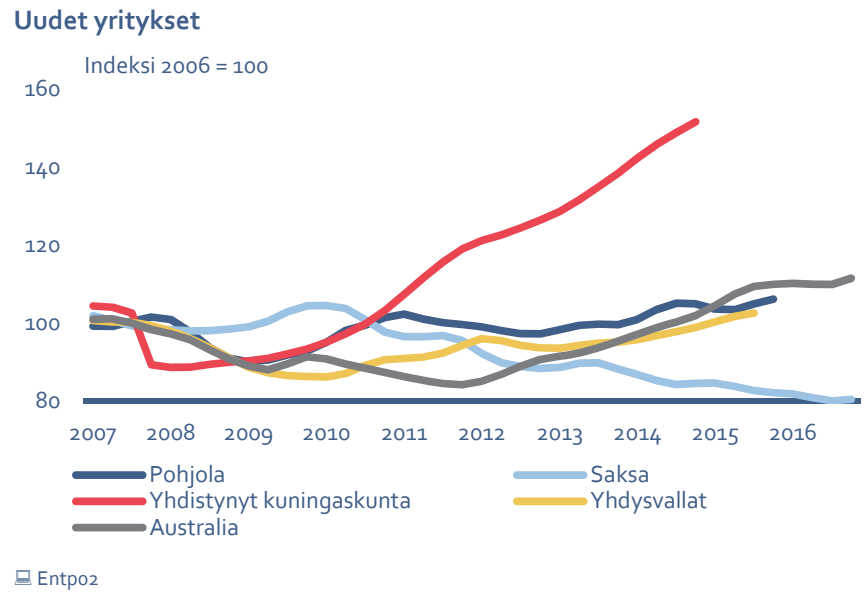

\section{Patentit 2016}

600 Miljoonaa asukasta kohti

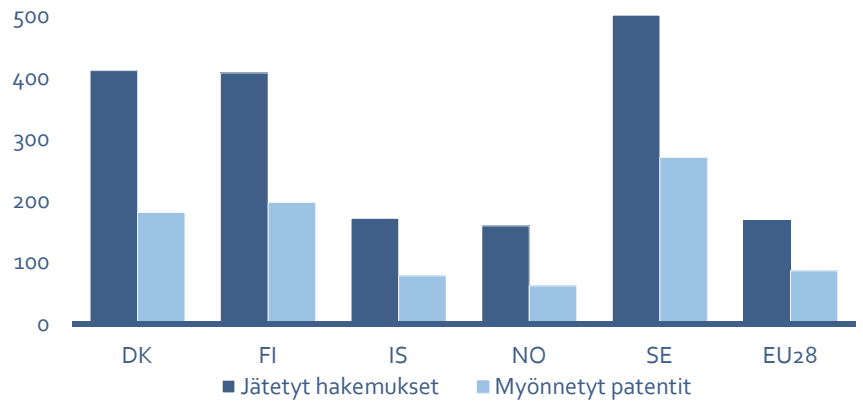

Pateo1 
Kulttuurialalla työskentelevät

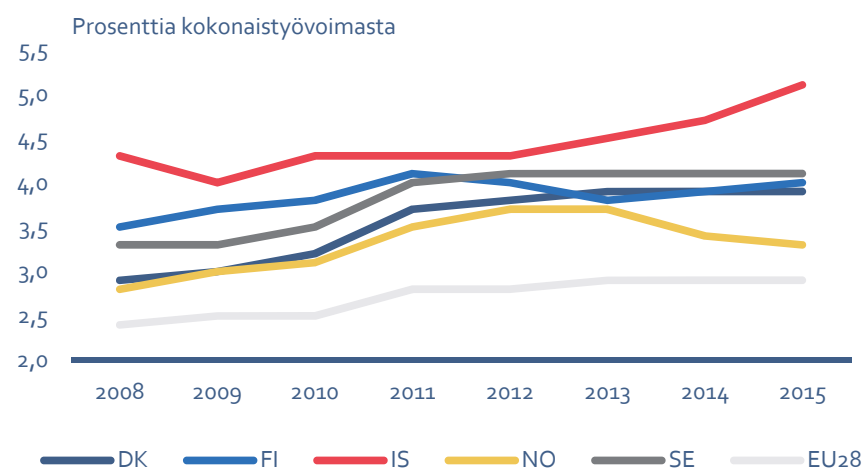

Cult23

Kulttuurin ja vapaa-ajan toiminnan julkinen rahoitus 2015

Euroa asukasta kohden

1600
1400
1200
1000
800
600
400
200

- 
Kulttuurin ja vapaa-ajan toiminnan julkinen rahoitus

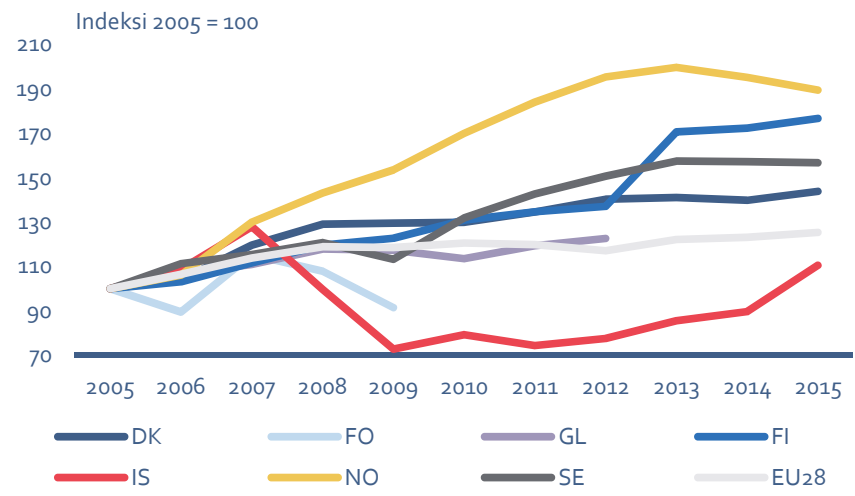

ㅁolt2o

\section{Elokuvaensi-illat 2016}

Prosenttia pohjoismaisista elokuvaensi-illoista

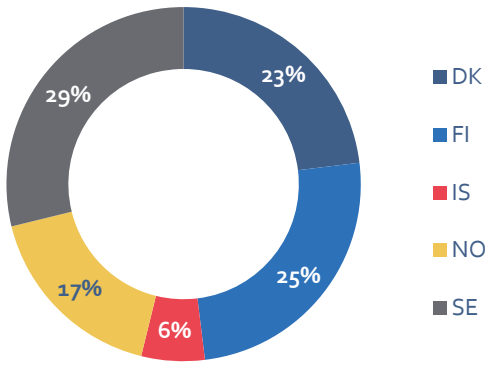

@ Culto5 


\section{Elokuvaensi-illat 2016}

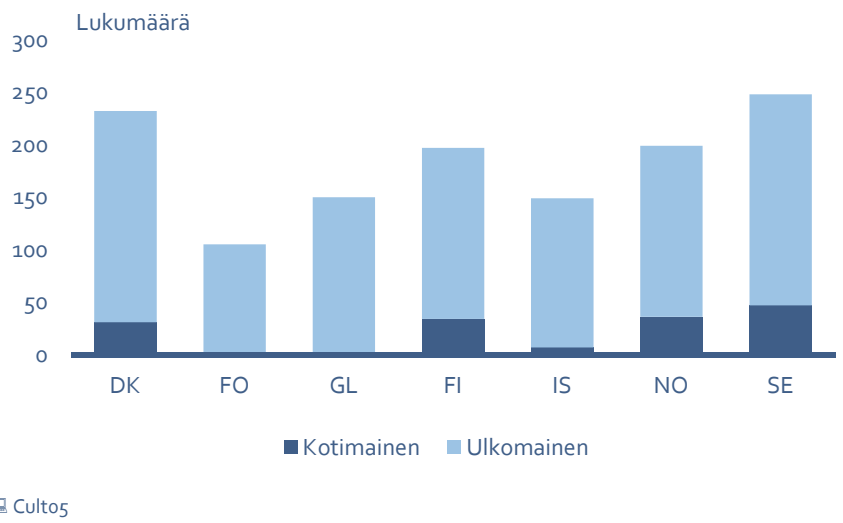

Teatterikäynnit 2016

Käyntien määrä sataa asukasta kohden

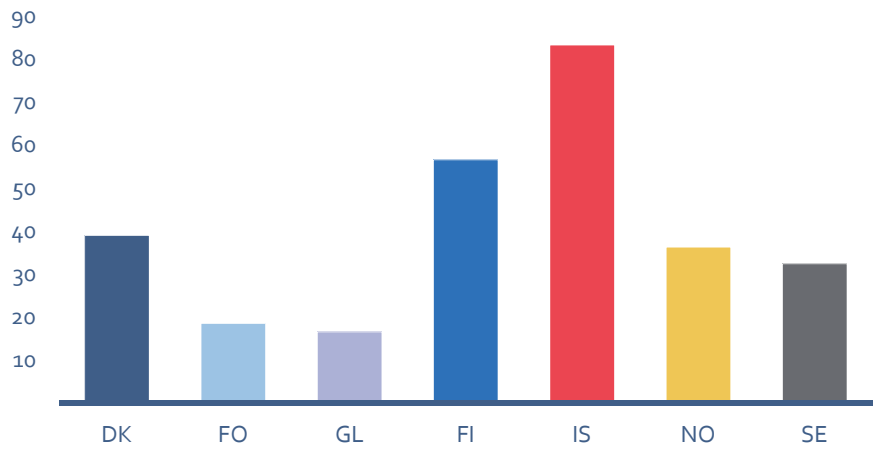

昌 Cult15. Suomi: tiedot vuodelta 2015. Islanti: tiedot vuodelta 2014. Ruotsi: tiedot vuodelta 2010. 
INNOVAATIO JA LUOVUUS 55 


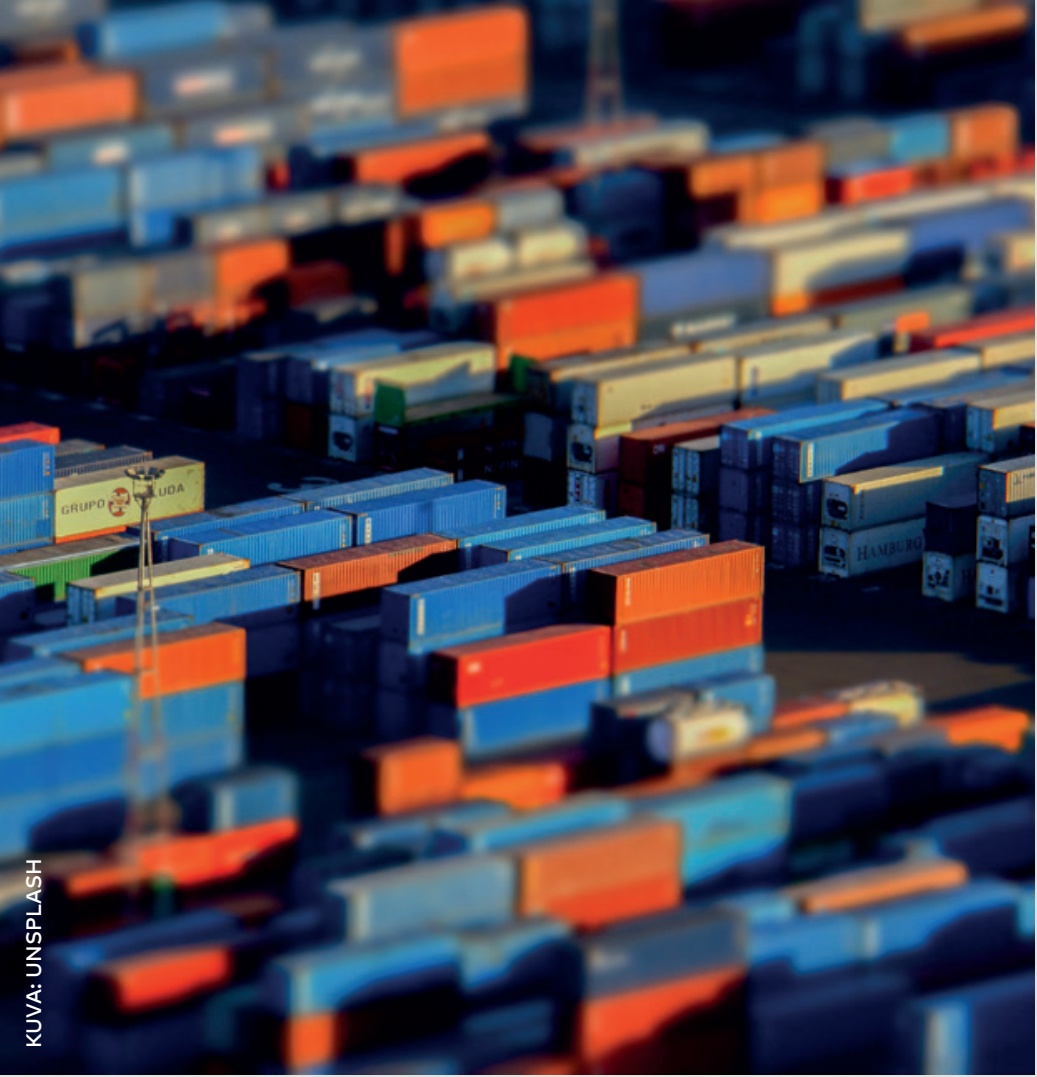

Noin viidennes Pohjoismaiden

ulkomaankaupasta on kauppaa muiden

Pohjoismaiden kanssa. 
Talous 


\section{AVAINLUVUT 2016 \\ Talous}

Työttömyys

prosenttia

TANSKA

SUOMI

ISLANTI

NORJA

RUOTSI

$$
6,3
$$

9,0

3,1

4,9

8,4 


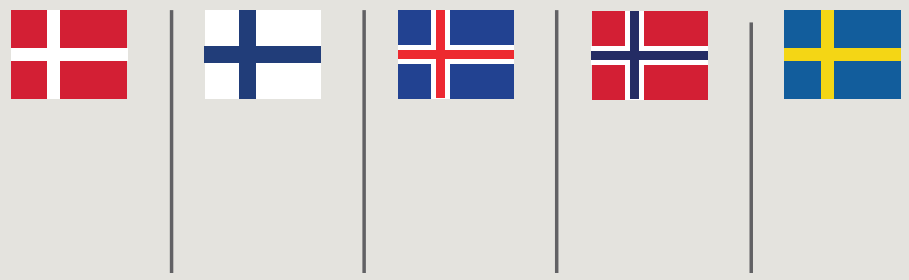

\section{Talouskasvu}

prosenttia

$$
\begin{array}{l|c|c|c|c}
1,3 & 1,4 & 7,2 & 1,0 & 3,3
\end{array}
$$

Vaihtotaseen ylijäämä

prosenttia BKT:sta

Korko

$$
8,2
$$

prosenttia

$$
\begin{array}{l|r|r|r|r}
0,3 & 0,4 & 2,8 & 1,3 & 0,5
\end{array}
$$

Julkisen sektorin ylijäämä

prosenttia BKT:sta

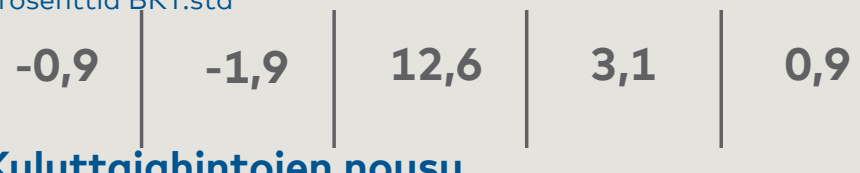

$$
\begin{aligned}
& \begin{array}{l|l|l|l|l}
0,3 & 0,4 & 0,8 & 3,9 & 1,1
\end{array}
\end{aligned}
$$




\section{BKT - reaalinen vuosikasvu}

Prosenttia

15

10

5

0

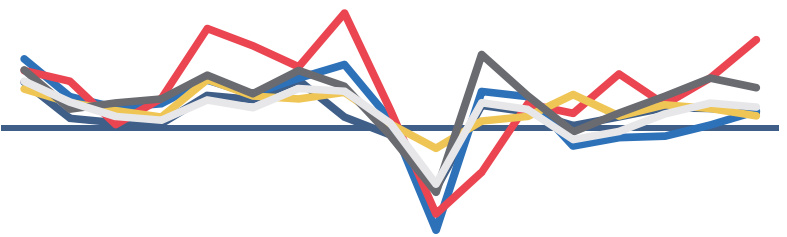

$-10$

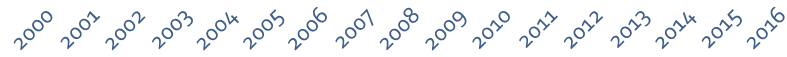

$$
\begin{aligned}
& \longrightarrow \mathrm{DK} \longrightarrow \mathrm{FI} \longrightarrow \mathrm{NO} \rightleftharpoons \mathrm{SE}=\mathrm{EA19}
\end{aligned}
$$

马 Naaco2. EA19: 19 EU:n jäsenvaltiota, jotka ovat 1. tammikuuta 2015 mennessä ottaneet euron valuutakseen.

\section{BKT asukasta kohden}

Euroa asukasta kohden ostovoimapariteetin (PPS) mukaan

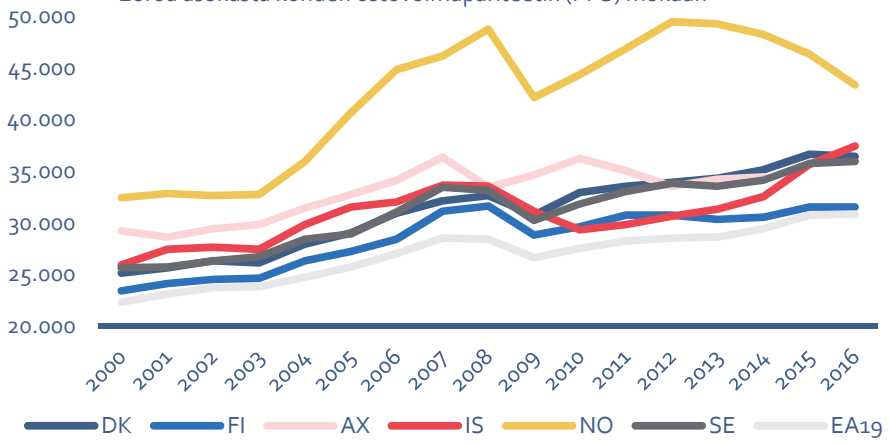

Naaco4. PPS: Purchasing power standards - ostovoimapariteetti, jonka avulla maiden välisiä hintaeroja on mahdollista vertailla eri hintatasosta huolimatta. 
BKT ja elintarvikkeiden hinnat 2016

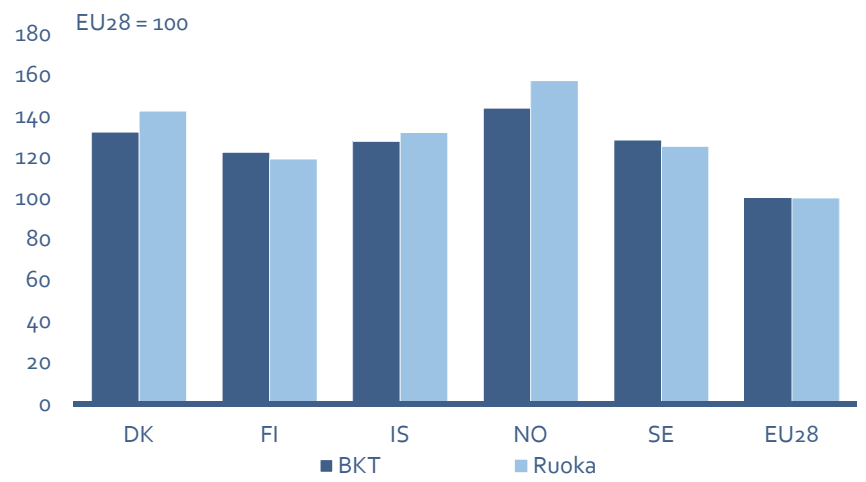

Prico3

\section{Asuntojen hinnat}

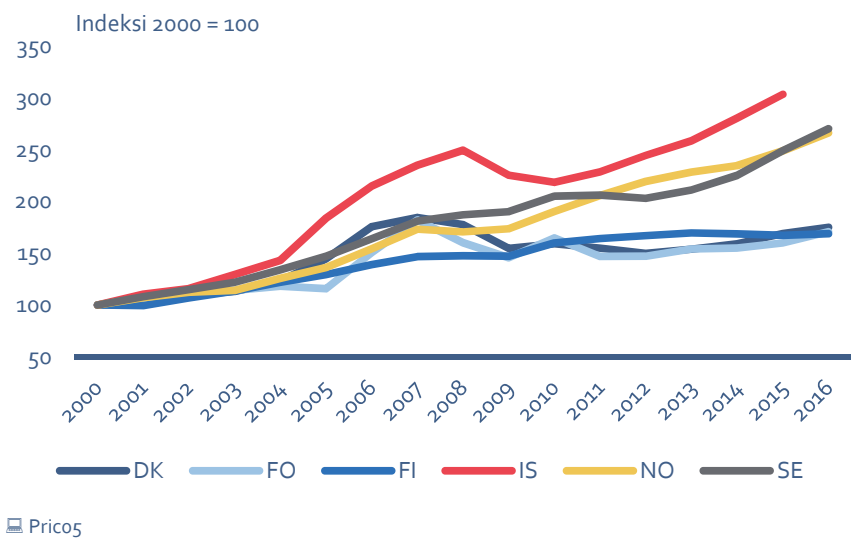


Pohjoismaiden välinen kauppa

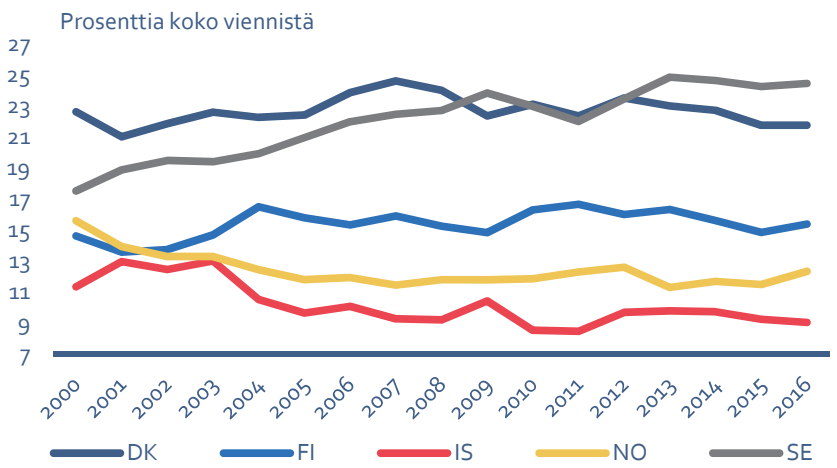

Eotr49

Pohjoismaiden välinen kauppa

Prosenttia koko tuonnista

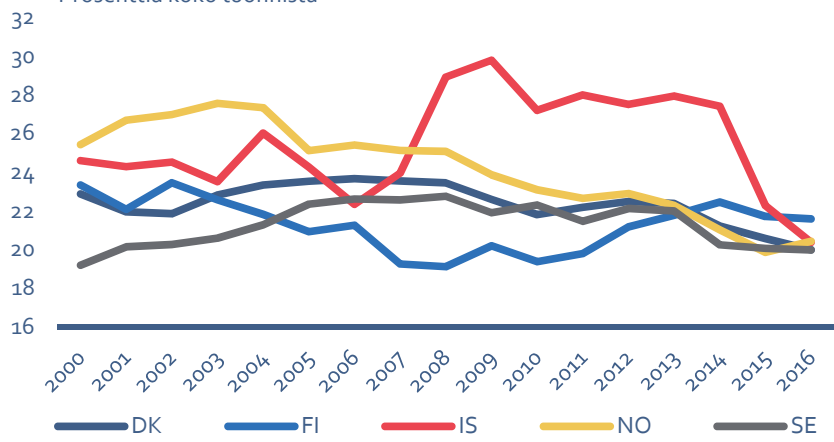

Fotr49 


\section{Kauppatase - vienti miinus tuonti}

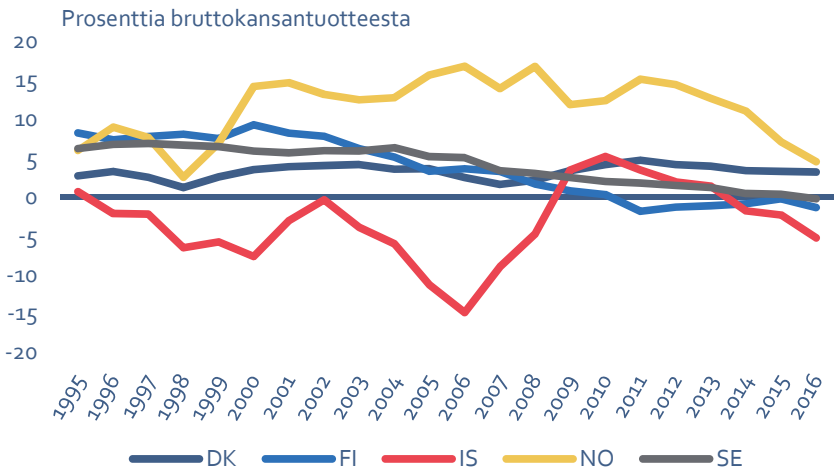

马otr49 ja Naaco1 
Pohjoismaiden ministerineuvosto

Nordens Hus

Ved Stranden 18

DK-1061 København K

www.norden.org

ANP 2017:749

ISBN 978-92-893-5103-4 (PRINT)

ISBN 978-92-893-5104-1 (PDF)

ISBN 978-92-893-5105-8 (EPUB)

ISSN 2414-6587 (ONLINE)

ISSN 2414-6579 (PRINT) 